Portland State University

PDXScholar

6-6-1975

\title{
Close Supervision Program: an Analysis of a Human Services Program
}

Thomas Wright Jr.

Portland State University

V. Henderson Trotman

Portland State University

Follow this and additional works at: https://pdxscholar.library.pdx.edu/open_access_etds

Part of the Criminology Commons, and the Social Work Commons Let us know how access to this document benefits you.

\section{Recommended Citation}

Wright, Thomas Jr. and Trotman, V. Henderson, "Close Supervision Program: an Analysis of a Human Services Program" (1975). Dissertations and Theses. Paper 1955.

https://doi.org/10.15760/etd.1954

This Thesis is brought to you for free and open access. It has been accepted for inclusion in Dissertations and Theses by an authorized administrator of PDXScholar. Please contact us if we can make this document more accessible: pdxscholar@pdx.edu. 
CLOSE SUPERVISION PROGRAM

AN ANALYSIS OF A HUMAN SERVICES PROGRAM

BY

THOMAS WRIGHT, JR.

AND

V. HENDERSON TROTMAN

A Practicum Submitted in Partial Fulfillment

of the Requirement for the Degree of

MASTERS OF SOCIAL WORK

PORTLAND STATE UNIVERSITY

1975 



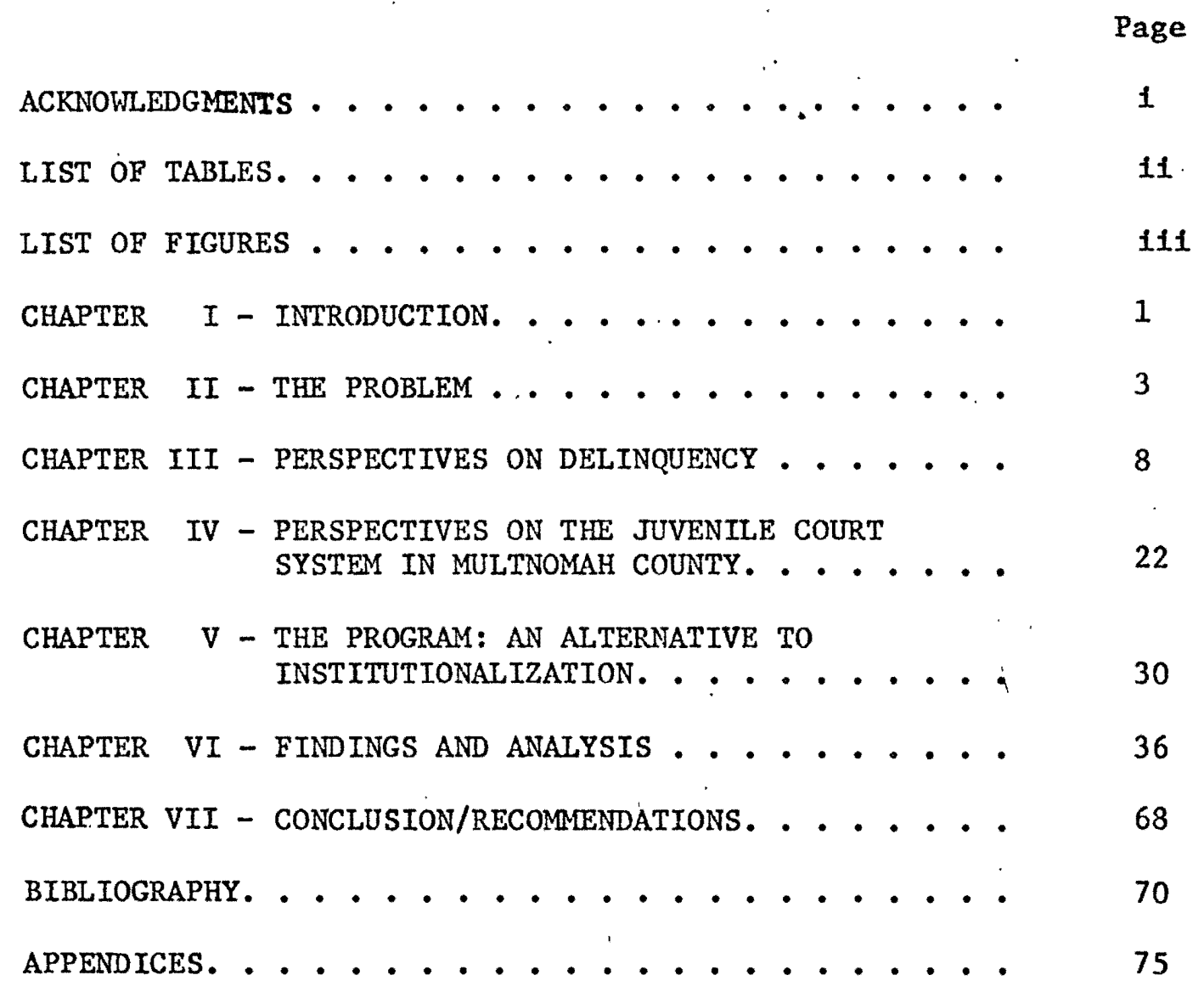




\section{ACKNOWLEDGMENTS}

We wish to express appreciation to the Juvenile Court and Portland Metropolitan Steering Committee personnel who gave us assistance in obtaining information on the Court, the Program, and the Youth. We are especially grateful to the women in the records section of the Donald $\mathrm{E}$. Long Home for the amount of work put forth in retrieving records for preparation of this study.

We are grateful to Drs. Gerald Blake and Gerald Frey for their assistance with this study.

We wish to thank our wives, Lyn and Joyce, for their patience and understanding while we all spent many anguished hours laboring to complete this study.

This study was partially funded by National Criminal Justice Graduate Research Fellowship Programs at Portland State University, Portland, Oregon. 
LIST OF·TABLES

Page

TABLE

10 - Objectives of the Program -

Juvenile Court Counselors. : . . . . . .53

11 - objectives of the Program -

Close Supervision Staff. . . . . . . .53

12 - Need for the Close Supervision Program -

Juvenile Court Counselors. . . . . . . .54

13 - Need for the Close Supervision Program -

Close Supervision Staff. . . . . . . 55

14 - Number Placed on Close Supervision

Program - Juvenile Court Counselors. . . . 55

15 - Comments re Eligibility Requirements -

Juvenile Court Counselors. . . . . . . .56

16 - Type of Youthful Offender for Close

Supervision Program Counselors . . . . . 57

17 - Type of Youthful Offender for Close

Supervision Program - Close

Supervision staff. . . . . . . . . 57

18 - Counselor Criteria for Program Use -

Juvenile Court Counselors. . . . . . . 58

19 - Eligible Youth Who Do Not Want to

Participate - Juvenile Court Counselors. • .59 
Page

TABLE

20 - Counselor's Role to Youth on

Close Supervision Program . . . . . . 60

21 - Services and Activities -

Close Supervision Staff. . . . . . . 61

22 - Ways Most Helpful to the Youth -

Close Supervision Staff . . . . . . 61

23 - Outcome of Youth Who Do Not Want to

Participate - Close Supervision Staff . . 62

24 - Expectations of the Close Supervision

Staff - Juvenile Court Counselors. . . . 62

25 - Expectation of Youth Placed on the

Program - Juvenile Court Counselors. . . 63

26 - Comments Regarding Rules and Restrictions -

Juvenile Court Counselors... . . . . . 64

27 - Avoidance of Further Law Violations While

on Close Supervision Program -

Juvenile Court Counselors. . . . . . 65

28 - Avoidance of Further Law Violations While

on Close Supervision Program -

Close Supervision Staff. . . . . . 65

29 - Why Some Youth Succeeded and Others

Failed - Juvenile Court Counselors . . . 66

30 - Changes in Services at the Donald E.

Long Home - Juvenile Court Counselors. . . 67 


\section{TABLE}

31 - Changes in Services at the Donald

E. Long Home - Close Supervision

Staff ............. . . . . . 


\section{LIST OF FIGURES}

Page

\section{FIGURE}

1 - Referral Composite Close Supervision Program. . . . . . . . . .

2 - Close Supervision Program Organizational Chart ......... 
"The process of making the criminal, therefore, is a process of tagging, defining, identifying, segregating, describing, emphasizing, making conscious and self-conscious; it becomes a way of stimulating, suggesting, emphasizing and evoking the very traits that are complained of. If the theory in relation of response to stimulus has any meaning, the young delinquent is mischievous insofar as it identifies him to himself and to the environment as a delinquent person."

F. Tannenbaum (1938) 


\section{CHAPTER I}

\section{INTRODUCTION}

Multnomah County, Oregon, like many other counties across the nation, faces the perplexing problem of meeting the needs of the youthful offender. Historically, and even in more recent times, juvenile court authorities have relied primarily on detention facilities to provide secure custody for youthful offenders. However, the continued increase in delinquency and a growing storm of critlcism of the juventle court have lead to a re-examination of current policy and a number of proposed changes on both the national and local level. Local concern and recognttion that too many youthful offenders were being held in the county detention home facilitated the move to adopt an alternative approach to detention. Local authorities were also urged by federal legislation (Juvenile Justice Act of 1974) to develop programs for the youthful offender in part due to the following factors: 1. the spiraling cost of maintaining exfsting facilities; 2. changing societal perceptions about the juvenfle justice system, and 3. the recognition that secure custody does not always serve as a deterrent to delinquency but often is only a breeding ground for future criminal careers. 
A polfcy change in Multnomah County with regard to detention of youthful offenders has led to the closure of some of the detention facilities at the Donald E. Long Home. The policy change was also responsible for the creation of an alternative program for the young offender. The alternative program called the Close Supervision Program was based on the philosophy that many of the youths held in detention do not require secure custody in the county's detention home while awaiting adjudication.

The authors surveyed the literature to examine the delinquency problem in light of "causal" factors, labeling and stigma, treatment, Institutionalization and alternatives to detention. This theoretical framework is provided in order to give meaning to the conceptualization of delinquency and the need for alternative programs.

The section on Perspective of the Juvenile Court system in Multnomah County will present information about the operation of the Court, and those factors which led to the establishment of the close Supervision Program.

The section on the evaluation of the findings and analysis will present data related to the Close Supervision Program's goal and obfectives, the outcome of the youth placed on the program, and perceptions of Court Counselors and Close Supervision Program staff about the operation of the program.

Because the Close Supervision Program is an integral part of the Juvenile Court in Multnomah County, the study will present an analysis on the operation of the program. 


\section{CHAPTER II}

THE PROBLEM

Youth across the Unfted States are beconing involved in criminal and delinquent activity at an ever increasing rate. The increase may be caused by family crises, school problems, peer pressures, unemployment, or a combination of factors. Whatever the cause of delinquency, the increase in youthful crines has reached crisis proportions. This Increase has stimulated a response from the federal government.

On the national level, the federal government has addressed the problem with the passage of the 1974 Juvenile Justice and Delinquency Prevention Act. According to Public Law 93-415 93rd Congress, S.821, 1974: Sec. 101 (a): "The Congress hereby finds that - (1) juveniles account for almost half the arrests for serious crimes in the United States today. . ." More specifically, Jackson (1973) states the problem in the following terms and reports that:

Over one million $(1,143,700)$ juvenile delinquency cases, excluding traffic offenses, were estimated as being handled by all fuvenile courts in the United States in 1973. - the overall increase for the country was 3 percent - - while at the same time the child population, aged 10 through 17 increased about 1 percent $(0.7)$. . Between 1960 and 1973, the number of delinquency cases more than doubled (124 percent increase) as compared to the 32 percent increase in the number of children aged 10 through 17. Jackson (1973:1). 
A further look at national trends reveals that a significant number of youths are being arrested for status offenses. According to the 1970 Census several hundred thousand youth were arrested for such status offenses as runaway, curfew, or general conduct Kassebaum (1974). Status offenses areviolations unique to minors because the violations would not be considered illegal if committed by an adult. Serlous offenses, on the other hand, are violations that would apply to youth and adults alike. According to the Youth Service Bureau Research Group (1975:7): "Approxlmately half of all arrests of young people in a typical year will be for such minor offenses as incorrigIbility, truancy, waywardness, or running away from home."

On the local level, a study conducted in Multnomah County, Oregon, showed that many youthful offenders were detained for offenses that were considered crimes only for minors.

A Study of Juvenile Detention in Multnomah County, Oregon, published in November,1973, revealed that many of the youth being detained at the Donald E. Long Home, a detention facility for the Multnomah County Juvenile Court, could be released to the community until their court hearing. It was also found that detention at the county home tended to be either very short ( 1 or 2 days) or extensively long (a month or more). They made this association because it was found that many youth were being detalned for status offenses. According to the study, operational costs could be reduced if an alternative program 
were developed so immediate release could be made available for youthful offenders who are neither a threat to themselves.nor to the community.

Statistics published by Multnomah County Juvenile Court in 1974 show the total referrals to the Juvenile Court in 1974 to be 7,003. Referrals to the Juvenile Court listed as "status offenders" (i.e., truancy, runaway, curfew violations, etc.) totaled 3,386. The referrals listed as "serious" totaled 3,617. Thus, almost one-half of the Juvenile Court caseload was comprised of status offenders. The total number of youthful offenders detained in secure custody was 3,260 in 1974 .

From the 1973 study published on Juvenile detention, and the statistics from Multnomah County Juvenile Court, officials became aware that Multnomah County needed some type of an alternative to detention. A position paper prepared in October 1974 by a Multnomah County Commissioner (1974:8) reports: "By 1973. . . there was a growing awareness that the deeper a child's involvement in the juven1le justice system, the greater the likelihood of continued involvement in the (juvenile or adult) system." A complementary philosophy states that children are best served by diversion or limited penetration instead of formal processing by the juvenile justice system. An Interview with the Director of Multnomah County Department of Human Services further explains the problems facing youthful offenders who are placed in detention facilities: 
Secure custody detention used for younsters who do not require it is damaging to them and unnecessarily costly to the county. The data regarding the use of this detention indicated that it was considerably overused. A large number (of youth) then being admitted could have been screened out prior to admission; another share could be placed in shelter care; and (still) another share could be placed under close supervision as an alternative to secure custody.

Some youngsters could function without being a threat to the community if they are provided the more intensive supervision that would be possible in a small caseload of about five, Goddard (1975).

In Multnomah County the annual cost of operating the Juvenile Court has been over one million dollars (Office of County Management, 1975). The cost to provide secure custody for youth who reside in Multnomah County will continue to be high as long as youth who might benefit socially and psychologically from an alternative program are, instead, held in secure custody at the Donald E. Long Home.

The youthful offender faces many problems when institutionalized. They may lose valuable time from school and employment. The youthful offender must try to complete all class assignments while being held in detention. The employed youth may lose gainful employment as a result of prolionged absence from work due to detention. The added social stigma attached to the label "juvenile delinquent" may also affect employment opportunities for youths and cause serious problems with teachers, other adults, and peers.

\section{Summary}

An examination of the 1iterature has shown increased involvement of youths in both serious and status law violations. The federal 
government has responded with the passage of the Juvenile Justice and Delinquency Act of 1974. Recognition of the over utilization of detention facilities for youthful offenders in Multnomah County has led to the establishment of alternative programs. The Close Supervision Program was established as an alternative to secure detention. The program is designed to reduce the need for institutionalization and the length of institutional care pending court hearings. 
"Juvenile delinquency as a term is not in vogue right now." -- Jackie Insley

In general, the use of the term "Juvenile delinquent" has been too broad or imprecise to convey a clear meaning. The definition of "juvenile delinquent" is mostly all inclusive, and begins with acts that are violations of criminal codes. Also included in the definition are disruptive family conditions, immoral conduct, school problems, and curfew violations.

\section{Misconceptions About Delinquency}

If a common definition is lacking for the term "delinquent," then misconceptions about delinquency will certainly appear in public attitudes and public laws. Who is a juvenile delinquent? The answer to this question depends upon different viewpoints. One may consider any youth who walks across his lawn to be a juvenile delinquent. Then, too, the youth who has long hair, wears dirty clothes or rides a motor bike could conceivably be a juvenile delinquent. Others view the juvenile delinquent as a violator of criminal law. In essence, then, juvenile delinquency means different things to different people. 
Public opinion is shaped by the mass media on virtually every issue; juvenile delinquency is not an exception. Schur (1973:11) points out that, "Gang violence is probably the dominant image of delinquency carried by the media." How delinquency is percelved by public officials and individuals in society will largely determine the type of response given to deal with the problem.

The Juvenile Court, by mandate, has given special attention to a range of youthful behavior because delinquency violates basic norms approved by society and requires corrective measures from an official institution. The official response to delinquent acts is to control the behavior of youths who violate socletal norms. Youths who do not abide by the rules challenge the legitimacy of the social system. The delinquent act is defined by two elements: first it is behavior that violates basic social norms and secondly, the behavior evokes a response from the juvenile justice system that these norms have been violated Schur (1973).

\section{Legal Definition of Delinquent Behavior}

There are, of course, legal definitions for juvenile delinquency. For example, Perlman states that:

Legally speaking, a juvenile delinquent is one who comnits a delinquent act as defined by law and who is adjudicated as such by an appropriate court. . . Most juvenile court laws define as delinquent a juvenile who violates any state or local law or commits any act that would be considered a crime if committed by an adult. In addition. . . most statutes define as delinquency acts which are violations of laws only when committed by children: truancy, running away, incorrigibility. . (Perlman 1968: 223-224). 
In the case of the youth who is considered to be incorrigible, spectal problems arise because any youth at one time or another could be brought to court on charges of incorrigibility. Lemert (1972:10) explains that:"incorrigibility when put into its social context is a term which many times connotes little more than conflict between a teen-age youth and parents, in which unreasonable demands are made by the latter and in which a probation officer becomes a partisan." Thus, much of what is considered to be a delinquency problem may not, in fact, be a problem that the court should handle, . or even try to solve. Juvenile Court involvement in such areas may be viewed as an overreach of the law (Lemert 1972). Who is the Youthful offender?

There are essentially two views expressed as to the characteristics of the typical juvenile delinquent. Perlman provides one of these views when he portrays the youthful offender as more likely to be:

a boy than a girl. . .he is generally about 14 or 15 years old when referred although he had exhibited behavior problems considerably earlier. His attitude is hostile, defiant, and suspicious. He is usually retarded in school work and in reading ability and shows a chronic history of truancy.

Delinquents, more frequently than nondelinquents, come from homes broken by death, divorce, or desertion or homes lacking in understanding, self-respect, stability, affection, and moral standards. (Perlman 1968:226).

Perlman (1968:226) goes on to explain that nondelinquents may come from these same environments, but that "such factors tend to produce disproportionate numbers of delinquents." 
Gibbons, in a statement on the nature of delinquency, portrays a different view on the youthful offender. He states that:

In a sense, given the broad character of delinquency laws in the United States, the potential population of "juvenile delinquency" is nearly infinite in size. That is, almost every juvenile in the United States could be considered a delinquent because almost every youngster engages in at least some minor acts of law violation. (Gibbons 1965:229).

Since the literature indicates that many youth suffer from much of what is defined as delinquency; then it follows that almost every youth is a potential delinquent.

\section{Causal Factors}

Study on the cause of delinquent behavior has focused on the family, with much attention being given to the parental role. (Cloward and Ohlin, 1965; West, 1973; Cavan, 1962). Cavan (1962) presents the argument that the single parent family is not a conclusive social indicator of delinquent behavior. He first addresses the issue of delinquency by examining certain supposed causes (1.e., family, culture) which may contribute to delinquency. The author states: ". . the contributing factors to delinquency are, as varied as the types of misbehavior grouped under this general term." The author continues, "Delinquents are neither 'feeble-minded nor superior'. They represent a cross section of the juventle population." (Cavan 1962:6-9). 
The next issue addressed by Cavan (1962) is the idea that most clinicians view youth who commit delinquent acts as emotionally maladjusted, when there may actually be no difference in the psychological adjustment of "delinquent" and "nondelinquent" youth.

Records may show some racial groups to have a monopoly on crime. The answer to who may be labèled "delinquent" may be found in the high arrest rate, court appearances, and convictions which are closely associated with slum neighborhoods (Cavan 1962). Although a high proportion of youthful offenders come from broken homes, this is not a proven cause of delinquency. Cavan (1962) explains that the employment of the mother who has left her children without supervision does not alone create delinquency, but is significant for understanding unfavorable family conditions. Research in the area of causal factors examines the family, culture, and psychological stability of youthful offenders in an effort to determine the causes of delinquent behavior. ${ }^{1}$ cloward and Ohlin (1960:53) examine the issue of the masculinity problem in a female-headed household. The authors contend, "Evidence is lacking as to the significance and the permanence of problems

1

Rose Glallombardo is editor of Juvenile Delinquency, A Book of Readings, a compilation of articles from research covering such subjects as the family, culture, and laws as they relate to delinquent behavior. 
of masculinity." The authors also criticize the cultural aspects

of delinquency because too many youths from "lower-class populations could be considered youthful offenders because of socioeconomic strata.

Treatment.

Some form of treatment has long been used in an effort to rehabilitate youthful offenders. Numerous methods of treatment have been utilized throughout the correctional system. Gibbons provides the following observation on what treatment means:
A provisional answer would be that therapy for correctional clients consists of explfeit or procedures deliberately undertaken to change those conditions thought to be responsible for the violator's misbehavior. Treatment implies some rationale or causal argument to the effect that the criminal behavior of the individual stems from some particular set of factors or conditions. (Gibbons 1965:130).

The two major types of treatment modalities used by correctional employees are individual psychotherapy and group therapy Gibbons (1965:129). The goal of the various treatment modalities is to either uncover individual problems or develop new behavioral norms. Basically, psychotherapy is used for individual problems and group therapy is used to change behavioral norms through group process. The length and frequency of the treatment modality usually depends on the youth and the percelved severity of the youth's problem. 
Gibbons (1965:146-147) has further divided the two major forms of therapy for youthful offenders into stx subtypes: "1. Individual 'Depth' Psychotherapy, 2. Group Psychotherapy, 3. Client Centered Therapy, 4. Group Therapy, 5. M1lieu Management, and 6. Environmental change."

Psychotherapy is a means of examining the internal psyche in. an effort to somehow alter or change the behavior of the youthful law offender. Gibbons (1965:142) states: ". .psychotherapy follows some procedure designed to reveal the internal workings of the person to the therapist and to the patient." The ain of psychotherapy, then, is to help the client realize what has caused his or her anti-social behavior. With this increased understanding the client should then be able to correct the anti-social behavior and prevent recurrence in the future.

Therapy for youth who have been institutionalized may be inappropriate if the treatment is at the request of the Juvenile Court and not the youth. In this case the youth may percelve therapy only as a requirement for release instead of help in the solution of his or her problems.

Some observers have argued that the Juvenile Court should define behavior that is criminal and treat the youthful offender in that manner. Harlow, Weber and Cohen note that: 
If a deviant behavior or condition is to be defined as not criminal then it would seem that an individual should not be compelled to accept treatment for that condition or behavior unless the condition is ruled inherent1y dangerous, and he should not be committed for other reasons except on a determination that he himself is dangerous or helpless. (Harlow, Weber and Cohen 1971a:9).

Thus in many respects, the Juvenile Court could be seen as sentencing the youth to therapy. (Kassebaum 1974).

Therapy as an approach to curb delinquent behavior has all but failed (Lemert, 1972). This may be due in part to the fact that the Juvenile Court is an agency of justice and therefore treatment efforts may only reinforce the "devlant". behavior of the youthful offender.

\section{Labeling and Stigma}

Over the years, Researchers such as (Tannenbaum, 1938, Lemert, 1972, Schur, 1973) have been concerned with the negative effects of labeling stigma on those youths who are processed by the Juvenile Court. What these studies have revealed is that the Juvenile Court invokes certain negative images on individuals with whom it has made contact. These images may be held by the individual himself and later reinforced by society in general. If contact with the court has resulted in the youth being labeled "delinquent," the label itself may lead to further involvement with the court.

The process by which the juvenile justice system labels the youth is one that creates a file for future use, assigns a case number, and assigns Juvenile Court personnel to the youth. Such a process will 
all but insure the youth will be kept labeled within the juvenile justice system. If a youth is placed in a special program and is told to obey special rules, the youth may fail to keep those rules, thereby furthering the image of failure and delinquency. Lemert (1972:13) writing on deviance, addresses this problem: "The specifics of this process lie in the reactions made to special status which set wards apart and special conduct standards which hold them accountable in ways not expected of other children." The youth placed in such a situation now has the original problem which brought him to the court's attention and a new set of rules by which to comply while being given "treatment" by Juvenile Court personnel. If the youth fails the special program, he will likely be perceived as a different type of youngster, which may further the perpetuation of stigmatization. The youth is then considered a deviant and as such, will generate a certain type of interaction from other individuals and public agencies. This special type of response from other individuals will cause the youth to identify with his new "ascribed role" and act the way a juvenile delinquent is supposed to act. Schur (1973:119) states that,". . the labeling approach stresses that the self-concepts and long-term behavior of rule violators are vitally influenced by the interaction between them and agents of social control."

The youth who has been stigmatized suffers greatly in future contacts with public agencies when seeking service. This same youth 
faces even greater problems if attempts are made to obtain certain types of employment. In response to these obstacles, the youth may be pushed to a delinquent, then criminal career.

\section{Institutionalization}

Youthful offenders are st11l institutionalized for status and serious offenses. Studies have shown that institutionalization is not required for every youthful offender. In fact, research indicates that institutionalization may actually make the problem of delinquency worse. Lemert explains:

- . In many cases the harm done to children and youth by contacts with these courts outweighs any benefits thereby gained. Moreover, the interaction between child and court and unanticipated consequences of the processing of a child in many instances contributes to or exacerbates the problem of delinquency. (Lemert 1972:1).

The institutionalization of youngsters does not act as a deterrent (as can be seen in the increase in delinquency) for other youths. Institutionalization has many ramifications for the youth who has been detained. In addition to loss of freedom, detention may have the added personal effect of loss of pride and self esteem. The youth's sense of integrity may be questioned by both himself and the court.

Detention means loss of freedom, removal of personal possessions, subjugation to arbitrary security rules, and survelliance in some juvenile halls by microphones and closed circuit television. Girls, on admission to detention, may have to submit to routine pelvic examinations, with the tmplications of posstble pregnancy or venereal disease: (Lemert 1972:11). 
Vague laws that give authority to the Juvenile Court to intervene into the lives of youths at any time can have serious consequences. Since it is apparent that detention as a method of preventing delinquent behavior has not worked, a new approach seems to be of urgent necessity.

\section{Deinstitutionalization}

As a response to the faflure of detention and institutionalization experimental programs are being established to decrease the population of youth in detention awaiting court adjudication. Utilization of the court's intake system as a method of reducing the court's involvement has not been totally effective as a diversionary process because too many youths are still being held in detention.

The diversionary process can be seen as an informal system beginning with the discretion of the police officer who decides whether or not to make an arrest. The second part of this diversionary process occurs at the disposition of the intake worker. The intake worker can decide whether to detain the youth, send him home or to foster care. The third part of this diversionary process is the informal hearing. Following the hearing, the youth can be informally released to his parents, to foster care, or placed on an alternative program. Harlow, et al (1971a:1) report, "The decision to divert an individual from judicial proceedings is affected by many factors, including the nature of the offense, the circumstances of its commission, the attitude 
of the victim, and the character of the accused." This process of diversion from the juvenile justice system should not be confused with recent diversion programs. There is still much discretion employed by law enforcement officials when a determination is made on the seriousness of the offense. Once a decision is made about the offense (either serious or status) another decision must be made in regard to where to take the youthful offender. The youthful offender can be taken to efther the court or a diversion program.

A serious problem can arise with this type of diversionary process through the over-use of the court's detention facilities. If the court assumes the responsibility for defining what constitutes serious and status offenses, then the court is in a position to decide which youths should be detained. In the case of the youthful offender, little distinction is made. Both serious and status offenders are held in detention. Lemert (1972:9) writes, "In a real sense it (the court) 'causes' delinquency by processing cases of children and youth whose problem might be ignored, normalized in their original setting, or dealt with as family, educational, or welfare problems."

Another problem with this diversionary method is that too many youth end up with the label of "delinquent." As can be seen from the literature on labeling and stigma, there are many problems associated with the label "delinquent." Writing on the use of discretion as a method of diversion, Harlow, et al states: 
Arrest data and court statistics indicate that 'most of the cases in the criminal courts consist of what are essentially violations of moral norms or instances of annoying behavior, rather than of dangerous crime,' and that many juveniles contacted by police for truancy, waywardness, or 'incorrigibility' end up in juvenile court with an adjudication of delinquency. (Harlow, et al 1971a:1-2).

An approach to the delinquency problem is the use of alternatives to detention through the use of a community-based program. Within the range of "community treatment" are such programs as Mobilization for Youth in New York City and the Chicago Area Project. These projects are aimed at some action-oriented approach to the prevention of delinquency.

An alternative to detention implies that the use of detention w111 no longex be used. The various types of alternatives can be seen in such terms as "comnunity treatment." Used in the framework of deinstitutionalization of youthful offenders, community treatment has lost all meaning. Harlow, Weber and Wilkins (1971b:1) ". . suggests that the idea of 'community treatment' has lost all descriptive usefulness except as a code-word with connotations of 'advanced correctional thinking' and implied value judgments against the 'locking up' and 1solation of offenders."

Some programs considered alternatives to institutionalization may well be considered Harlow et al (1971b:3) in terms as ". . intensive intervention in lieu of institutionalization. . Intensive intervention 
as an alternative to institutionalization would imply exactly that -- a means of handling the offender without incarceration."

The use of detention raises the question of the need for supervision at all if the offense is considered non-dangerous. The use of such an intensive program can be seen as an important improvement of the traditional methods of custodial care of youthful offenders; however, the purpose of an alternative to detention is to avold the negative effects of the court and detention. If the purpose is to avoid negative effects of labeling and stigma that are associated with detention, then institutionalization is neither necessary nor beneficial for those youth who are status offenders. 
CHAPTER IV

PERSPECTIVES ON THE JUVENILE COURT SYSTEM IN MULTNOMAH COUNTY

The Juvenile Court Act, which the Oregon Legislature passed in 1905, led to changes relative to the care and treatment of youth across the state. Previously, the care and treatment of youth was handled by various charitable organizations. With the passage of the new act, Multnomah County became more directly"involved in maintaining and advancing methods of treating its dependents and delinquents." The act defined a "dependent child" and a "delinquent child" in the following terms. The"dependent child" as:

- . any child in destitute circumstances, or any child without parental care and control, or any child begging or peddling upon the streets, or any child living among disreputable companions, or in disorderly houses, or whose home was an unfit place for such a child by reason of its parent's cruelty, immorality or neglect, or any child under 12 years of age found singing or playing in the streets for hire.

The "delinquent child" as:

- . any incorrigible child or one who violated any criminal law or municipal ordinance, who was a truant from school, or one who associated with vicious companions or was found in bawdy houses, saloons, or gambling houses.

(East, $1939: 34-35)$,

This act, which was based on the philosophy that youth should be helped rather than punished, gave the court jurisdiction over youth until they reached the age of 16 years. The act also stipulated that youth be detained in a suitable place away from adult criminal influence 
and that no youth under 12 years of age be admitted to any fail. (The Bunction of the Multnomah County Juvenile Court and Donald E. Long Home, 1974).

During the next few years, various amendments resulted in changes to the original act. The first set amendments gave the court furisdiction over youth until they reached the age of 18 years. For those youth who were already involved with the court, the age over which the court had jurisdiction was raised to 21 years. Such changes, according to Judge Frazer, were necessary since the court ". . .had lost control of several. children just at the time when control and restraint were most needed." (East, 1939:43).

The amendments changed the definition of dependency to include ". . any child found living in a saloon, or with drunken parents, or any child found begging in the streets." (East, 1939:43).

The amendments also provided for paid probation officers, the expenses of the court, and for the erection of a detention home, which was built shortly thereafter (East, 1939:43).

Other amendments in subsequent years resulted in the creation of the Court of Domestic relations. This Court, which was created specifically for Multnomah County, was given "original and exclusive jurisdiction over all children under 18 years of age, and in all procedures contributing to the delinquency of a minor." A few years later, another amendment to the act abolished this Court and created in its place, the 
Department of Domestic Relations in the Circuit Court for Multnomah County. (Report 1943-1953:5). Unlike the Court of Domestic Relations, the new Court's powers were limited as its jurisdiction did not include cases involving support, desertion, and illegitimacy (Bel1, 1939). Unt1l 1950 when the Donald E. Long Home was opened to replace the Frazer Detention Home, the operation of the Court remalned basically unchanged as no new amendments to the act were passed.

With the opening of the Donald E. Long Home, the Court was better prepared to provide care for the increasing number of youth who were being referred for dependency and delinquency. During the years 19491953, dependency referrals to the Court rose from 684 to 1087, an increase of 58 percent. For the same period, delinquency referrals to the Court rose from 1496 to 1882 , an increase of 211 percent (Report 1949-1953).

The Increased volume of work at the Court made the need for an additional judge, who was immediately chosen, acute. Another change resulted in the use of the term Juvenile Court Counselor to replace the previously used title, Probation officer. (Report 1949-1953). Because of the continued increase in delinquency in Multnomah County, several community groups held a public meeting to express their concern over this increase. The success of their meeting led to the formation of the Citizens Committee on Juvenile Delinquency. which was made up of persons appointed by the Mayor and the County Commissioners. 
The comittee was assigned the task of studying all aspects of juven1le delinquency in Multnomah County. Soon thereafter, six subcommittees were formed from the overall committee and each selected for careful study, one of the following areas: law enforcement agencles, welfare services, character building agencies, juvenile court and institutions, family.life, and school and employment. After evaluation of the various programs, the committee then affirmed that juvenile delinquency was caused by multiple factors such as: inconsistent discipline, problems of mental health, poverty neighborhood, school failure and truancy, lack of wholesome recreation, multiple temptations of communications, and poor adult examples. As a result of their study, the committee made recommendations which included:

1. Institute a school for parents of delinquent children.

2. Enlargement of foster home programs.

3. Strengthening of law enforcement agencies and the Juvenile Court.

4. The creation of additional Child Guidance clinics.

With regard to the Juvenile Court, the committee also recommended that a full time Court, five days a week, be brought into operation, that legally trained referees be employed, and that a Deputy District Attorney be appointed to serve as a legal advisor and as a prosecutor In some cases. (Multnomah County Juvenile Court and The Donald E. Long Home, 1958:7-8). 
Within a couple of years, many of the recommendations were being Implemented to facilitate a smoother operation of the Court. Referrals for dependency and delinquencycases continued to increase to the extent that in 1965, there were 6761 referrals to the Court. (Multnomah County Juvenile Court and The Donald E. Long Home, 1965).

What was also very apparent during these years is that many of the referrals were bringing many more new families within the jurisdiction of the Court. Reasons such as the Increased use of drugs, the hippie culture, the race riots, and truancy referrals were all cited as being responsible for the increase. For example, referrals for drugs alone increased by 294 percent in 1967. (Multnomah County Juvenile Court and The Donald E. Long Home, 1967).

The period was also replete with a number of developments on both the national and local level, which had an impact on the operation of the Court. For example, the Supreme Court's decision in the case, Kent vs. U.S., 383 U.S. 591 (1966) enabled youth who were brought before the Court to have "due process of law". as guaranteed in the Constitution. A year later, the Supreme Court again ruled in The Matter of Gault 387 U.S. 1 (1967) that the provisions of "due process" as provided by the Fourteenth Amendment be applied to juvenile proceedings. This was to be applied to the extent that it included "the notice of allegations (charges), right to counsel and appointment 
of counsel, right against self-incrimination, and the right of confrontation of the witness against the child." Three years later, the Supreme Court in another case, The Matter of Winship, 397 U.S. 358 (1970) required "proof beyond a reasonable doubt as the guarantee of proof in some juvenile cases:"(Laws Relating to Children, 1972: XV-XV1).

In 1967, the President's Commission on Law Enforcement and Administration of Justice published a report on Juvenile Delinquency and Youth Crime. The report, in many instances, was very critical of the operation of the Courts across the nation. Edwin Lemert was among those authors who critically examined some of the longcherished bellefs about delinquency, its causation and control. Lemert in his article, "The Juvenile Court - Quest and Realities," pointed out the deleterlous aspects of wardship, stigma and labelling on youth referred to the Courts. (Task Force Report: 91-105). As a result of these developments on the national level, the Legislative Interim Juvenile Code Committee was created to prepare a revision of the law as it relates to youth in the State of Oregon. The comittee's work resulted in many new revisions to comply with the trends developing on the national level. Their recommendations sanctioned the Juvenile Court's jurisdiction in any case involving a person who is under 18 years of age and: 
(1) Who has violated any law of the United States, or a state, or city; or

(2) Who is beyond the control of his parents, or anyone having custody; or

(3) Whose behavior, conditions, or circumstances are such as to endanger his own welfare or the welfare of others; or

(4) Who is dependent for support upon a child care agency that needs the help of the Court in planning for his best interests; or (5) Whose parents or lawful guardian have abandoned him, failed to support him, or to provide him with education as required by law, or have abused him physically or emotionally; or

(6) Who has run away from home. (Youth Faces the Law, 1972).

Other recommendations have reduced the Court's jurisdictional powers. One revision lowered the age of wardship from 21 to 18 years of age. Another revision enables youth who meet certain criteria prescribed by law, to have their records destroyed. (Laws Relating to Children, 1972).

Another development on the local level to have an impact on the operation of the Court, was a position paper titled, "Care of Juveniles in Multnomah County." Writing critically about some of the operations of the Court, the author pointed out that "detention tends to draw the child further into the system." (Clark, 1974:17). The publication of this paper was partly responsible for the closure of some of the 
facillties at The Donald E. Long Home, the reduction in counseling staff, and the creation of alternative programs to care for youth who might otherwise have been held in detention.

Apart from these recent changes, the Court has employed a variety of approaches to control spread of dependency and delinquency. These approaches include: the use of professionally trained counselors to treat families referred; the use of psychiatrists and psychologists to provide more accurate diagnoses and assessments, and the continuation of neighborhood-based programs in high delinquency areas.

Other components of the Juvenile Court System which enable Multnomah County to exercise its jurisdictional power include: Youth Service Bureaus, Group Homes, Foster Homes, Tr̈affic Department, the School System, and many other agencies which, at times, also provide service to the families involved with this court.

\section{CONCLUSION}

It is very evident that the Juvenile Court System In Multnomah County has changed its focus and direction over the years to meet the needs of the community, and in response to criticism. That some components of the System are still developing should be evident by changes and programs currently taking place. One such program, the Close Supervision Program, which was recently started, is designed to meet a need within the Court System. 
CHAPTER V:.

THE PROGRAM

AN ALTERNATIVE TO INSTITUTIONALIZATION

On August 1, 1974, the Close Supervision Program, a project developed by Multnomah County Department of Residentfal Services and contracted to the Portland Metropolitan Steering Committee E.0.A. Inc., was started in Multnomah County, Oregon. The Close Supervision Program was patterned after the Home Detention Program in St. Louls, Missouri. The Close Supervision Program shares a dual relationship with Portland Metropolitan Steering Committee E.0.A. Inc. and Multnomah County Juvenile Court as a result of a contractual agreement. (See appendlx H ).

Designed to reduce the need and length of secure custody at the Donald E. Long Home, the Close Supervision Program was established to prevent youthful offenders from being held in detention pending disposition of a hearing. The Close Supervision Program accepts only the youthful offender who is 1 . referred to the court for a law violation, 2. a resident of Multnomah County and comes within the jurisdiction of the court, 3. an offender whose offense is not sertous enough to make court release a danger to himself/herself or to the communtty, and 4. In agreement to be avallable for the court hearing. 
31

The Close Supervision Program is staffed by a supervisor who coordinates program activities and is responsible for four.Community Youth Workers. Each Community Youth Worker has a caseload of five to six youthful offenders. Youthful offenders are referred by their Juvenile Court Counselors and are screened to meet the following criteria (as defined by the Close Supervision staff) before they are accepted to the program.

1. That the youth has a home available, either the natural or a surrogate.

2. That the case is not so notorious as to render the juvenfle unacceptable to the community.

3. All parties involved with the case (Community Youth Worker, parents, Court Counselor, and the juvenfle) agree to maximum participation in the program. Sweeney (1974).

Community Youth Workers are required to make two face to face contacts with each youth. Daily contacts enable the Community Youth Worker to provide activities and service for the youth which may include hiking, swimming, and employment referral. The Community Youth Worker maintains constant liaison with people in the community who have a significant relationship to both the youth and the program. (See Appendix G)

The staff is responsible to tailor specific rules to insure maximum participation by each youth. Such rules included for the 
youth are: 1. house custody, 2. no phone calls, 3. no visitors, and 4. curfew (See Appendix G). Failure to obey the rules or the commital of a new offense, results in the youth being dropped from the program immediately. The program allows for a minimum of 21 days and a maximum of 41 days the youth may receive service from the program.

of the 133 youths referred by the court to the program during the study period (August 1, 1974, through December 31, 1974) 35 youths have been dropped.

If the youth obeys the rules, continuation on the program may be for the maximum time allocated and at this point is terminated and considered a success.

In an attempt to serve the youth, the following goal and objectives were developed by the Close Supervision Program.

A. To provide a program for supervision and control of youth in Multnomah County who would otherwise be placed in The Donald E. Long Home.

B. By implementation of this program, to reduce the number of youths held in secure detention pending disposition and implementation of Court plan. 
ACTIVITIES OF CLOSE SUPERVISION PROGRAM:

Two dafly contacts with each juvenile:

Meeting with Juvenile Court Counselors.'

Meetings with other staff, parents, school officials, employers, and other interested parties.

Transportation to and from court hearings when necessary.

Taking juveniles bowling, back packing, and to other recreational activities (Sweeney, 1974). 
FIGURE 1

REFERRAL COMPOSITE

CLOSE SUPERVISION PROGRAM

-

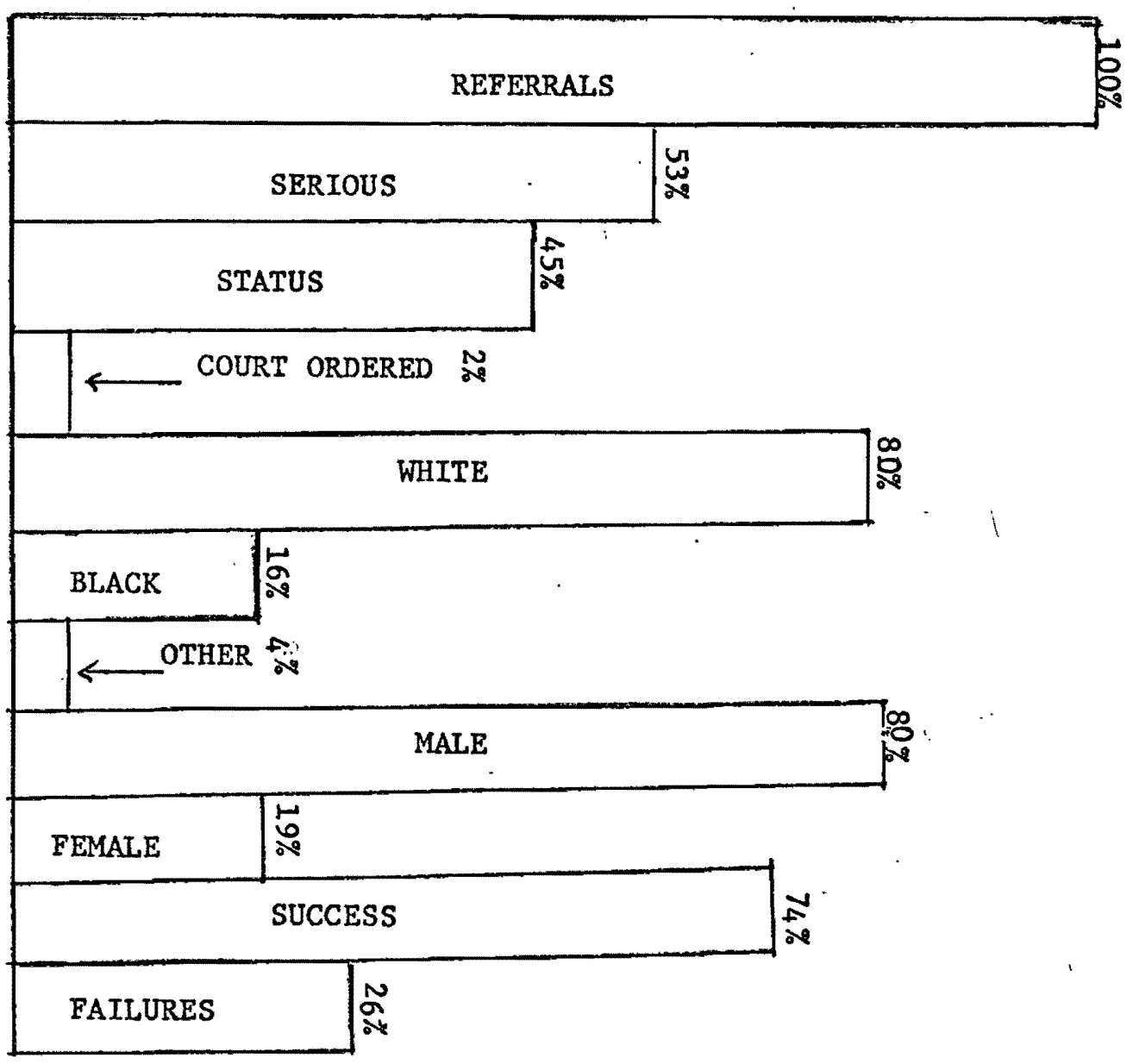


FIGURE 2

CLOSE SUPERVISION PROGRAM

ORGANIZATIONAL CHART

Close Supervision Coordinator

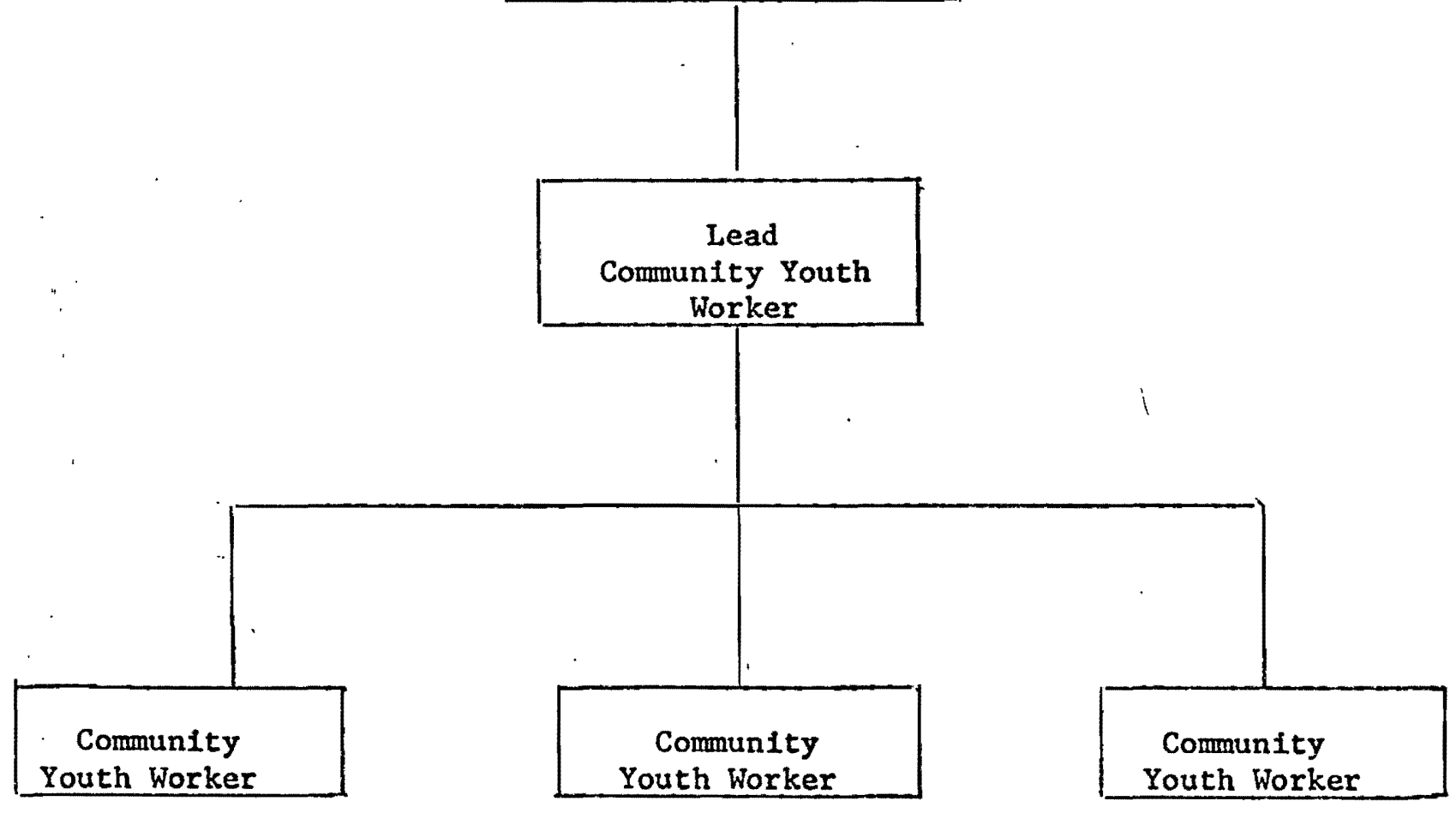




\section{CHAPTER VI}

\section{FINDINGS AND ANALYSIS}

SECTION I

The evaluation was designed to answer four questions:

1) Do the serious and status youthful offenders require institutionalization in Multnomah County? 2) Does the Close Supervision Program contribute to the labeling and stigmatization of the youthful offender? 3) Did the Close Supervision Program meet its stated obJectives? 4) Is the Close Supervision Program an alternative to secure custody of the youthful offender? This section will address the above questions.

1) Do the serious and status youthful offenders require institutionalization in Multnomah County?

As noted in the literature, institutionalization to prevent and control delinquency may result in Increased problems for the youthful offender and may also exacerbate the problem of delinquency. As a result of institutionalization, the youthful offender may sense a loss of pride and self-esteem and may also be labeled "delinquent" which could result in the youthful offender being perceived differently by himself, his peers, and other members of society. Such varied perceptions about the youthful offender may result in limited employment and educational opportunities which, according to Lemert (1972) may lead to further delinquent behavior. 
In more recent years, growing criticism about the operation of the Court relative to the use of institutionalization, especially for non-serious youthful offenders, and the cost of institutionalization has resulted in a number of policy changes on the national and local level.

On the national level, Congress in 1974, passed the Juvenile Justice and Delinquency Prevention Act which, in part, stressed the critical need for alternatives to institutionalization. On the local level, after it became more evident that institutionalization was damaging to youthful offenders and unnecessarily costly to the County, local authorities responded to the delinquency problem with the closure of some of its detention facilities, and the creation of the Close Supervision Program.

During the period August 1, through December 31, 1974, 133 youthful offenders were released from institutionalization at the Donald E. Long Home, and placed on the Close Supervision Program. This figure of 133 youthful offenders represents about 9 percent of the total number (1426) who were institutionalized at the Donald E. Long Home during the same period. Included in this figure (133) were 131 youthful offenders who were placed on the Program by their counselors, 71 of whom (53 percent) were placed for sertous offenses, and 60 (45 percent) for status offenses. Two percent of the total 133 were placed on the Program directly by the Court. There were 
107 (80 percent) males and 26 (20 percent) females. Thts total included 106 whites ( 80 percent) 21 blacks ( 16 percent) and 6 youth ( 4 percent) from minorities other than blacks. Nine of these offenders ( 7 percent) ranged between ages $10-12,74$ (56 percent) between ages $13-15$, and 50 (37 percent) between $16-18$.

TABLE 1

NUMBER OF YOUTH ASSIGNED TO THE CLOSE SUPERVISION PROGRAM BY AGE, SEX AND RACE

\begin{tabular}{|l|c|c|c|c|c|c|c|c|}
\hline \multirow{2}{*}{ AGE } & \multicolumn{9}{|c|}{ MALE } & \multicolumn{7}{c|}{ FEMALE } \\
& BLACK & WHITE & *OTHER & TOTAL & BLACK & WHITE & *OTHER & TOTAL \\
\hline $10-12$ & 2 & 5 & - & 7 & 1 & 1 & - & 2 \\
$13-15$ & 6 & 51 & 1 & 58 & 1 & 15 & - & 16 \\
$16-18$ & 8 & 30 & 4 & 42 & 3 & 4 & 1 & 8 \\
& & & & & & & & \\
\hline
\end{tabular}

*Includes minorities other than blacks.

During the period covered, youthful offenders spent an average of 7.2 days institutionalized at the Donald E. Long Home before their placement on the Close Supervision Program. The average length of stay on the Close Supervision Program for those who succeeded was 29 days and for those who failed 12 days.

of the 133 youths placed on the Program, 98 of them (74percent) were listed as successful and 35 (26 percent) were dropped from the Program as failures. 
The 74 percent rate of success was assessed to determine which type of youth did better on the Program. The following Tables will present the data on the variables age, sex, race, type of referral offense, length of stay at the Donald E. Long Home, number of prevlous offenses, and types of previous of offenses.

The variables will be defined as follows:

1. Age - Youth who were placed by the Juvenile Court between $10-12$, $13-15$ and $16-18$.

2. Sex - male and female.

3. Race - black, white and other (other includes minorities other than black).

4. Referral offense - offense for which the youth was referred to the Juvenile Court which was classified as either serious or status.

5. Length of stay at the Donald E. Long Home. Days spent in detention were classified at None, $1-5$, and 6 or more.

6. Number of previous offenses - Alaount of offenses prior to referral offense which were classified as None, $1-5$, and 6 or more. 7. Types of previous offenses - types of offenses prior to referral offense which was classified serious, status and both. The dependent variable used for this study vas outcome ( success or failure). Success means the continuation on the Program for the maximum time allotted; and failure means discontinuation on the Program for a 
violation of the contract or for a new offense. To determine whether the relationships between the independent and dependent varlables were empirically valid or due to chance, the Chi Square at .05 confidence level was used.

TABLE 2

AGE BY OUTCOME

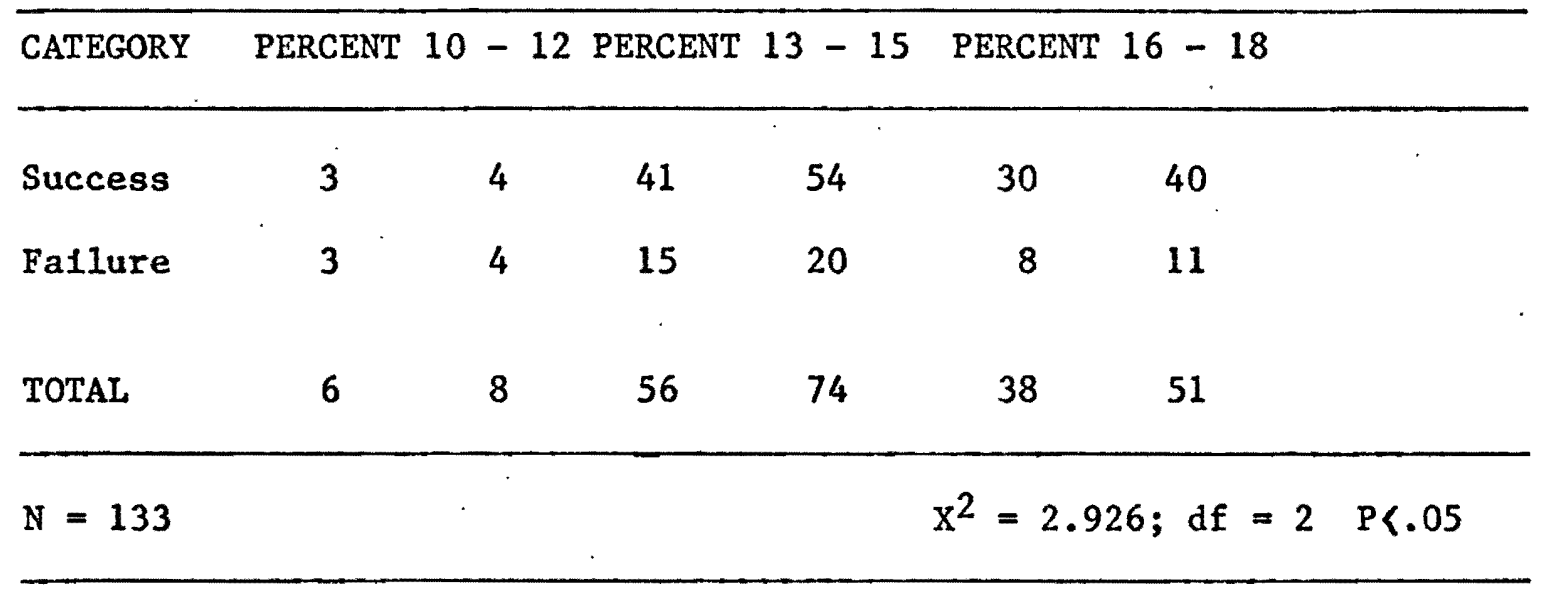

In Table 2 the relationship between age and outcome is presented. of those youthful offenders who were between ages 13 through 15,54 (41 percent) succeeded and 20 (15 percent) failed. of those ages 16 through 18, 40 (30 percent) succeeded and 11 ( 8 percent) failed. There appears to be a slight relationship between age and success, but not approaching statistical significance. 
TABLE 3

SEX BY OUTCOME

\begin{tabular}{lcccc} 
CATEGORY & PERCENT & MALE & PERCENT & FEMALE \\
\hline Success & 60 & 79 & 14 & 19 \\
Failure & 21 & 28 & 5 & 7 \\
TOTAL & 81 & 107 & 19 & 26 \\
\hline $\mathrm{N}=133$ & & & $\mathrm{X}^{2}=0.658 ;$ df $=1 . P<.05$
\end{tabular}

Data on the youthful offender by sex and outcome is presented in Table 3. As can be seen, 79 (60 percent) succeeded and 28 (21 percent) failed, whereas, 19 (14 percent) females succeeded and 7 ( 5 percent) falled. From the data given in this Table, there is no association between sex and a successful outcome.

TABLE 4

RACE BY OUTCOME

CATEGORY PERCENT WHITE PERCENT BLACK PERCENT OTHER

\begin{tabular}{llllllll}
\hline Success & 56 & 75 & 14 & 19 & 3 & 4 & \\
Failure & 23 & 31 & 2 & 2 & 2 & 2 & \\
TOTAL & 79 & 106 & 16 & 21 & 5 & 6 & \\
\hline $\mathrm{N}=1.33$ & & & & $\mathrm{x}^{2}=7.007 ;$ & df $=2$ & $\mathrm{P}>.05$ \\
\hline
\end{tabular}


In Table 4, information is presented on the youthful offender by race and outcome. Out of 106 whites ( 80 percent) who were on the program, 75 (56 percent) succeeded and 31 (23 percent) failed. There were 19 blacks (14 percent) who succeeded and 2 (2 percent) who falled. of the others (youths from minorities ather than Black), 4 (3 percent) succeeded and 2 ( 2 percent) falled. The figures in the table appear to Indicate that there was a significant difference between race and outcome at the.05 percent confidence level. These figures would then Indicate that there was a greater tendency for Blacks to succeed than whites or other minorities once placed on the program.

TABLE 5

REFERRAL OFFENSE BY OUTCOME

\begin{tabular}{lcccccc}
\hline CATEGORY & PERCENT & SERIOUS & PERCENT & STATUS & PERCENT & COURT ORDERED \\
\hline Success & 41 & 55 & 32 & 42 & 1 & 1 \\
Failure & 12 & 16 & 13 & 18 & 1 & 1 \\
TOTAL & 53 & 71 & 45 & 60 & 2 & 2 \\
\hline N $=133$ & & & $\mathrm{X}^{2}=1.521 ; \mathrm{df}=2$ & $\mathrm{P}$ & $<.05$ \\
\hline
\end{tabular}

As indicated in Table 5, information is presented by referral, offense and outcome. Fifty-five of those (41 percent) placed on the 
Program for serious offenses succeeded as compared to 16 (12 percent) who failed. Of the 60 placed for status offenses, 42 of them (32 percent) succeeded and 18 (13 percent) failed.. These figures show that there appears to be no significant difference between referral offenses and outcome.

\section{TABLE 6}

LENGTH OF STAY IN DONALD E. LONG HOME BY OUTCOME

\begin{tabular}{lrrrrrr}
\hline CATEGORY & PERCENT & NONE & PERCENT & $1-5$ & PERCENT & 6 OR MORE \\
\hline Success & 23 & 30 & 38 & 51 & 12 & 16 \\
Failure & 9 & 12 & 14 & 19 & 4 & 5 \\
TOTAL & 32 & 42 & 52 & 70 & 16 & 21 \\
\hline N = 133 & & & & & $\mathrm{X}^{2}=0.161 ;$ df $=2$ & $\mathrm{P}<.05$ \\
\hline
\end{tabular}

As indicated in Table 6, information is presented by length of stay in the Donald E. Long Home and outcome prior to placement on the Close Supervision Program. As can be seen, 51 of the youthful offenders (38 percent) who were successful spent 1 to 5 days in detention. This is contrasted to 19 (14 percent) who failed and also spent 1 to 5 days in detention. There were also 30 youthful offenders who succeeded (23 percent) who spent no days in detention and 12 youthful offenders 
( 9 percent) who failed that spent no time in detention. From this data in the table, there appears to be no significant difference between the length of stay in the Donald E. Long Home and outcome.

TABLE 7

NUMBER OF PREVIOUS OFFENSES BY OUTCOME

\begin{tabular}{|c|c|c|c|c|c|c|c|c|}
\hline CATEGORY & PERCENT & NONE & PERCENT & $1-5$ & PERCENT & 6 & $\mathrm{OR}$ & MORE \\
\hline Success & 21 & 28 & 42 & 56 & 11 & & 14 & . \\
\hline Fallure & 4 & 5 & 19 & 26 & 3 & & 4. & \\
\hline TOTAL & 25 & 33 & 61 & 82 & 14 & & 18 & \\
\hline$N=133$ & & & & $x^{2}$ & 506 ; & $=3$ & $\mathbf{P}$ & $<.05$ \\
\hline
\end{tabular}

Table 7 shows the variables number of previous offense and outcome. Fifty-six of the youthful offenders ( 42 percent) who succeeded had 1 to 5 previous offenses whereas 26 youthful offenders (19 percent) who falled also had 1 to 5 previous offenses. Another 28 youthful offenders (21 percent) that succeeded had no previous offenses and 5 youthful offenders ( 4 percent) who failed and who also had no previous offenses.

There appears to be no significant difference between number of previous offenses and outcome. 


\section{4}

TABLE 8

TYPES OF PREVIOUS OFFENSES BY OUTCOME

\begin{tabular}{lcccccccc}
\hline CATEGORY & PERCENT & NONE & PERCENT & SERIOUS & PERCENT & STATUS & PERCENT & BOTH \\
\hline Success & 21 & 28 & 19 & 25 & 11 & 15 & 21 & 28 \\
Failure & 4 & 5 & 8 & 10 & 6 & 8 & 10 & 14 \\
TOTAL & 25 & 33 & 27 & 35 & 17 & 23 & 31 & 42 \\
\hline $\mathrm{N}=133$ & & & & $\mathrm{x}^{2}=3.838 ;$ & $\mathrm{df}=3$ & $\mathrm{P}$ & $<.05$ & \\
\hline
\end{tabular}

Table 8 presents information on types of previous offenses by outcome. Twenty-eight (21 percent) of those who were successful on the program did not have any previous offenses. Of the other successes, 25 (19 percent) were for serious offenses, 15 (11 percent) were for status offenses. Among the fallures, 5 ( 4 percent) did not have any previous offenses, whlle 10 ( 8 percent) had been placed for serious offenses. Tests show that there appears to be no significant difference between types of previous offenses and outcome.

Except in the case of race and outcome where there was a significant relationship, there appears to be no statistical relationship of outcome to any of the other variables.

From this assessment, the authors believe that those youth placed on the program may have been influenced to succeed or fail as a result 
of other variables which were not tested in this study. Such variables could include family conditions, ecological reasons, personal desire to conform to the rules of the program, and other possible unknown reasons.

An analysis of the data presented in the above tables reveals that both serious and status offenders tended to succeed on the Close Supervision Program. Inference from the statistics would indicate that the majority of youthful offenders in Multnomah County could benefit from alternative programs (for example, the program herein mentioned) and do not necessarily require institutionalization.

A continuation of the evaluation will now examine the following question:

2. Does the Close Supervision Program contribute to the labeling and stigmatization of the youthful offender?

As noted in the literature, (Tannebaum 1938, Lemert 1972, and Schur 1973), the labeling and stigma which occurs when youth are processed by the juvenile court may damage the youth's perception of himself and cause him to "act" in accordance with the label "delinquent." This may also set him apart for special services by the court and could lead to further involvement in the justice system.

The juvenile court, by its very nature as an institution which dispenses justice for law violations, is likely to invoke certain 
images of individuals who have come into contact with the court. On the other hand, the Close Supervision Program due to its close affiliation with the juvenile court, and as a result of-its contractual agreement contribute, somehow, to the problem of stigma and labeling in the following ways:

1) Through its acceptance of youth only from the said juvenile court. These youth may have already been processed, assigned a file and case number, Court Counselor, and possibly made a ward of the Court.

2) Through its contractual agreements which require staff to make two face to face contacts with each youth daily. These contacts may possibly be made at home, school, place of employment, or among peers.

3) Through the use of specially tailored rules which the staff is empowered to make. These rules include house custody, no phone calls, and restrictions from seeing certain friends.

To further evaluate the Close Supervision Program, the authors will address the question:

3. Did the Close Supervision Program meet its stated objectives?

The two objectives that appear in the Program's contract are as follows:

"1. To provide a program for supervision and control of youth in Multnomah County who would otherwise be placed in the 


\section{7}

Donald E. Long Home."

"2. By implementation of this program, to reduce the number of youths held in secure detention pending disposition and implementation of Court plan." (Close Supervision Program, 1974.):

To determine whether the Program met its stated objectives, the following criteria were arbitrarily decided on by the authors, since the Program's objectives were not "measurable" and "time bounded" (Multnomah County Program Objective Productivity System, 1974 ).

1. That the Close Supervision Program serves the number of youth it was contracted to serve.

2. That the Close Supervision Program diverts more than 80 percent of the youthful offenders from committing a new offense or violating the Close Supervision contract.

3. That the Close Supervision Program operates at a cost less than the current cost of the juvenile detention home and maintains an effectiveness rate above 80 percent.

With the use of the above criteria, an analysis of the Program's objectives will be presented:

Objective 1: To provide a program for supervision and control of youth in Multnomah County who would otherwise be placed in the Donald $\mathrm{E}$. Long Home. 
Outcome: The contractual agreements between Multnomah County Department of Residential Services and Portland Metropolitan Steering Comnittee - EOA, (Inc.), showed that the Close Supervision Program was budgeted to provide service to 30 "clients" per day (see Appendix H). From the analysis, it was found that the Program served about 26 "clients" per day during the study period. The difference may be attributed to the fact that during the first month of operation, only 15 "clients" were placed on the program. However, in subsequent months the Program averaged about 30 youth per month, which indicates that the Program did meet the objectives.

TABLE 9 POPULATION COMPARISON

DONALD E. LONG HOME AND CLOSE SUPERVISION PROGRAM

\begin{tabular}{lcccc}
\hline MONTH & $\begin{array}{l}\text { TOTAL MONTH } \\
\text { POPULATION AT } \\
\text { DONALD E. LONG } \\
\text { HOME }\end{array}$ & $\begin{array}{c}\text { CLOSE } \\
\text { SUPERVISION } \\
\text { PROGRAM } \\
\text { ADMISSIONS }\end{array}$ & $\begin{array}{c}\text { CLOSE } \\
\text { SUPERVISION } \\
\text { PROGRAM CASES } \\
\text { CLOSED }\end{array}$ & $\begin{array}{c}\text { CLOSE } \\
\text { SUPERVISION } \\
\text { PROGRAM CASES } \\
\text { DROPPED }\end{array}$ \\
\hline August & 249 & 15 & 1 & 1 \\
September & 316 & 22 & 8 & 7 \\
October & 347 & 30 & 23 & 5 \\
November & 261 & 36 & 21 & 11 \\
December & 253 & 30 & 23 & 11 \\
\hline TOTAL & 1,426 & 133 & 76 & 35 \\
\hline
\end{tabular}


Objective 2: By implementation of this program to reduce the number of youths held in secure detention pending disposition and implementation of court plan.

Outcome: With the creation of the Close Supervision Program in August 1974, 133 (9 percent) of those youthful offenders, who were held in secure custody at the Donald E. Long Home, were released to the Program during August through December 1974. As a result. of the services and activities provided, the Program diverted 98 youth ( 74 percent) of those placed on the program.

Based on the Close Supervision Program's budget, the estimated total program cost for salaries during the study period was $\$ 17,650.00$ for the Close Supervision staff. Other estimated costs were: $\$ \mathbf{\$ 7} .50$ per day to serve the youth on the Program; $\$ 145,000.00$ covering the total program cost for salaries during the study period for Juvenile Court workers in residential services; and $\$ 26.00$ per child-care day to serve the youth at the Donald E. Long Home. 
TABLE 10

ESTIMATED EXPENDITURES

OF

DONALD E. LONG HOME AND CLOSE SUPERVISION

AUGUST 1 - DECEMBER 31, 1974

DONAID. E. LONG HOME

CLOSE SUPERVISION PROGRAM

Number

of

19

5

Staff

Amount

of

$\$ 145,000.00$

$\$ 17,650.00$

Salaries

Number

of

Youths

1,426

Cost

Benefit

$\$ 26.00$ per day cost

$\$ 7.50$ per day cost

The figures reveal that the Close Supervision Program operated at a cost less than that at the Donald E. Long Home.

Though the Program operated at a cost far below the rate of the detention home, its failure to meet the 80 percent rate of success as set forth in the criteria, may be due to such factors as poor 
screening, and attitudes of the youth placed on the program.

4. Is the Close Supervision Program an alternative to secure custody for youthful offenders?

As noted in the contractual agreements between Multnomah County Department of Residential Services and the Portland Metropolitan Steering Committee, EOA, (Inc.), the Close Supervision Program was designed as "an alternative to secure detention for juveniles" (See Appendix G).

Throughout the period under review, a total of 133 youthful offenders ( 9 percent) were released from the total population of 1426, who were institutionalized at the Donald.E. Long Home. of these 133 youth who were placed on the Close Supervision Program, 98 (74 percent) succeeded.

Some of the Court Counselors,like the Close Supervision staff In response to the above question, indicated that they regarded the program as an alternative to secure custody.

That the Close Supervision Program operated in accordance with its contractual agreements; that the majority of the youth placed on the program succeeded; that respondents to the questionnaires viewed the program as an alternative to secure custody; all tend to suggest that the program can be considered as an alternative to detention. 


\section{SECTION II}

This. section of the evaluation will focus on the views of the staff regarding the Close Supervision Program. As part of the evaluation, two open-ended questionnafres (see Forms $A$ and $B$ in the appendix) were administered by the authors to 27 Juvenile Court Counselors some of whom work in nelghborhood based agencles, and 4 staff members of the Close Supervision Program. The purpose for administering the questionnalres was to assess the respondents' views regarding the operation of the program. The use of open-ended questionnal res was designed to allow for flexibility in responses to the questions.

Most of the court counselors ( 71 percent) were white males who on an average was about 35 years of age. Of those responding, 37 percent had a master's degree and 33 percent a bachelor's degree in one of the Social Sclences. They also had averaged about 11 years experfence in the Juvenile Justice System (see appendix A).

The typical member of the Close Supervision Program is likely. to be a white male, under 35 years of age, who had worked on an average of 4 years in the Juvenile Just1ce System. The Individual was 1kkely to have attended college, and majored in one of the Soctal Sciences (see appendix A). 
The Need For The Program

Responses in the tables below will present information on the two questions which were designed to assess the counselors and staff's views regarding the need for the Close Supervision Program.

In response to the question regarding the objectives of the program, 19 counselors (59 percent) and 4 staff members (50 percent) indicated that they saw the objectives designed to provide supervision. Another 13 counselors ( 41 percent) and 2 staff members ( 25 percent) noted that the objectives were designed to serve as an alternative to detention and to insure no new law violations respectively.

TABLE 10

OBJECTIVES OF THE PROGRAM

Juventle Court Counselors

Response

To provide supervision

To serve as an alternative

$\mathbf{N}=\mathbf{3 2}$
Frequency Percent

19

13

59

41

\section{TÁBLÈ 11}

OBJECTIVES OF THE PROGRAM

Close Supervision Staff

Response

To provide superviston

To insure no new law violations

To insure youth will be avaflable for court hearing
Frequency Percent

450

25

2
25

25

$N=8$ 
As previously noted in the literature, studies have shown the need to change from the current method of Institutionalizing youthful offenders to some other alternative. In response to this need, the Close Supervision Program is designed to be an alternative to institutionalization in Multnomah County. In answer to the question regardIng the need for the Close Supervision Program, 9 counselors ( 31 percent) and 3 staff members ( 50 percent) gave different reasons about the need for the Program. Whereas the counselors felt that the Program was needed because of reduced detention facilities; the staff, on the other hand; held the opinion that the Program was needed as an alternative to detention: Another 5 counselors ( 17 percent) and 1 staff member (17 percent) believed that the Program was needed since it sets up a structure for the youth, and since there were large case loads at the juventle court. Another response given by 3 percent of the sald counselors stated that the Program takes difficult minors.

TABLE 12

NEED FOR THE CLOSE SUPERVISION PROGRAM Juvenile Court Counselors

\section{Response}

Reduced detention facilities

Sets up a structure for the youth Reinforces counseling effort Question the need

No need

No response

When Juvenile Detention Home is not necessary

other

$N=29$
Frequency Percent

$\begin{array}{rr}9 & 31 \\ 5 & 17 \\ 2 & 7 \\ 2 & 7 \\ 2 & 7 \\ 2 & 7 \\ 4 & \\ 3 & 14 \\ & 10\end{array}$


TABLE 13

\section{NEED FOR THE CLOSE SUPERVISION PROGRAM \\ Close Supervision Staff}

Response

$$
\begin{aligned}
& \text { Alternative to detention } \\
& \text { Too large a case load } \\
& \text { No response } \\
& N=6 .
\end{aligned}
$$

Frequency Percent

3

$1 \quad 17$

$2 \quad 33$

\section{The Use of The Program}

To get an Idea of the use of the program, the respondents were asked several questions. To the question about the number of youth they had placed on the program, 27 of the counselors stated that they had referred from about 1 to 20 youth to the program.

\section{TABLE 14}

\section{NUMBER PLACED ON CLOSE SUPERVISION PROGRAM Juvenile Court Counselors \\ Response \\ Number}

Between 1 and 3

Between 4 and 6

Between 7 and 10

Between 11 and 20

Unknown amount.
13

4

3

2

5

$N=27$

The above Table shows that the program was used by the Juventle Court Counselors, although the degree of use varied from counselor to counselor.

Table 15 presents the responses from counselors concerning the eligibility requirements. Those 15 counselors (56 percent) who re- 
sponded positively listed such comments as: okay, fine, flexible, and good. Seven counselors responded negatively and 11sted: time period ( 3 weeks) is too short, too broad - program accepts all kinds of referrals, and youth should not be held in detention to be eligible for the program.

TABLE 15

COMMENTS RE ELIGIBILITY REQUIREMENTS Juvenile Court Counselors

Response

Positive comments Negative comments No response
Frequency 15 7 5
Percent 56

$N=27$

A review of the positive comments concerning the elfgibility requi rements tends to suggest that the majority of the counselors were satisfied with the criteria for placement of youth on the program.

In answer to the question regarding the types of youth that should be placed on the program, 25 counselors ( 76 percent) indlcated that the youth should be one who can be maintained in the community. Their answer is in accord with the two responses from the progran's staff (50 percent) who noted that the program is designed for both status and serious offenders. Other responses from the counselors showed that. 3 of them ( 9 percent) feit that the youth should not be a runner, whereas, a Close Supervision staff member (25 percent) noted that the program is designed for all types of referrals. 
TABLE 16

TYPE OF YOUTHFUL OFFENDER FOR CLOSE SUPERVISION PROGRAM Juvenile Court Counselors

\section{Response}

One who can be maintained in the community

One who is not a runner

Must have cooperation of parents

Status cases

Youth in school program

Depends on avallability room in detention

No response

$N=33 \ldots$

\section{Frequency Percent}

$\begin{array}{rr}25 & 76 \\ 3 & 9 \\ 1 & 3 \\ 1 & 3 \\ 1 & 3 \\ 1 & 3 \\ 1 & 3\end{array}$

\section{TABLE 17}

TYPE OF YOUTHFUL OFFENDER FOR CLOSE SUPERVISION PROGRAM Close Supervision Staff

\section{Response}

Both status and serfous

All referrals

Status
Frequency Percent

250

125

125

$N=4$

The responses to this question would tend to suggest why so many different types of offenders, with offenses ranging from curfew violations to homicide, were placed on the program (see appendix B). Another question on the questionnaire for counselors asked what criteria they used to select youth for the Close Supervision Program. As can be seen from the appendix (p. 90), criteria for placement on the program were: 1) he or she has a home avallable, elther the natural one or a surrogate; 2) the case is not 80 notorious as to render the 
juvenile unacceptable to the parties involves with the case (parents, Juvenile Court Counselor, community youth worker assigned); and 3) that the juvenile agrees to maximum participation in the program. As the following table indicates, the counselors used a variety of criteria in their dectsion to place a youth on the Close Supervision Program. Criteria listed by 11 respondents (28 percent) showed that counselors based their decision on whether the youth was a risk. Another 5 counselors (13 percent) mentioned that they based their decision on whether the parents agreed to participate or not.

\section{TABLE 18}

COUNSELOR CRITERIA FOR PROGRAM USE

\section{Response}

Juvenile Court Counselors

Youth who is not a risk

If parents agree to program

Youth's past history of runaways

Where controls in the home are not adequate

Admitted to detention

Other

Cases decided at preliminary.

Usual pressure from supervision

Attitude toward the court

Number of current detention population

Almost all status offenses

Does not feel the program is applicable

Close to weekend

If youth can be placed in foster care

\section{Frequency Percent}

11

5

3

13

8

38

3.8

38

$2: 5$

$2 \cdot 5$

$2: .5$

25

13

13

13

13

$N=40$

From the above, it is evident that a varlety of criteria, some of which is very subjective, Influenced the counselors decision to place youth on the Close Superviston Program.

One of the questions asked of the counselors was, what would happen 
to a youth who meets the elegibility requirements but does not want to participate on the Close Supervision Program? The 18 respondents (58 percent) Indicated that the youth would be held in detention, This response is contrasted by 3 persons (10 percent) who indicated that the youth might be released. Other respondents noted that the case would be referred to the judge or referee ( 6 percent), that the youth usually want to particlpate to get out of detention ( 3 percent), and that non-participation would mean the youth did not meet the eligibility requirements ( 3 percent).

TABLE 19

ELIGIBLE YOUTH WHO DO NOT WANT TO PARTICIPATB Juvenile Court Counselors

\section{Response}

Would be held in detention

Do not know - no alternative around

Might be released

Some placed away from home

Judge or referee would decide

Depends on youth

Want to participate to get out of detention

Non-participation would not meet requirement

No response

\section{Frequency Percent}

18

2

3

2

2

1

1

1

1
58

6

10

6

6

3

3

3

3

$\mathbb{N}=31$

The fact that detention was the only alternative avallable to youth causedthe authors to express the following concerns:

1. The need for other programs in lieu of detention.

2. The need for deinstitutionalization of status offenders (45 percent of the total placed on Close Supervision Program 
during the study pertod were status offenders (Figure 1, p.34).

3. Why detention, since, as noted in the 1iterature, detention may be destructive and could possible lead to further involment in the justice system?

of those counselors responding to the question regarding the counselors' role, 27 of them ( 82 percent) felt that their role was to provide ongoing counseling. Four of the counselors (12 percent) indicated that they did not become involve with the youth who were placed on the program.

TABLE 20

COUNSELORS' ROLE TO YOUTH ON CLOSE SUPERVISION PROGRAM Juventle Court Counselors

\section{Response}

To provide ongoing counseling Little participation

No response

Other
Frequency Percent

27

$4 \quad 12$

13

13

$N=32$

Since many of the respondents indicated that they still provided ongolng counseling to the youth placed on the program, the authors query :

1. Does the Close Supervision staff provide information to the counselors which is then utflized in planning for the youth more effectively?

2. Does little participation mean that the respondents who do not provide counseling better serve the remainder of their caseload? 
61.

As regarding the services and activities provided, 2 respondents (30 percent) answered the question by stating that supervision is one of the basic services provided by the program. Other respondents mentioned that they provided job referrals, educational opportunities, and assistance with problems in the home.

TABLE 21

\section{SERVICES AND ACTIVITIES PROVIDED \\ Close Supervision Staff}

Response

Superviston

Job referrals

Re-entry Into school system

Help solve home problems

No activities
Frequency Percent

$3 \quad 30$

$2 \quad 20$

220

220

110

$N=10$

To the question, in what ways were you most helpful to the juveniles on the Close Supervision; 4 of the responses (50 percent) showed that the staff felt that they were most helpful to the youth through the use of daily contacts. Two other responses (25 percent) from the staff indicated that they were helpful by setting an example which the youth could follow. Tho other answers varied.

\section{TABLE 22}

WAYS MOST HELPFUL TO THE YOUTH

Close Supervision Staff

Response

Frequency Percent

Consistency through daily contacts

Setting an example 


\section{2}

There was unanimous agreement found in the answer to the question regarding the outcome of youth who do not want to participate in the Close Supervision Progran as all of the staff (100 percent) stated that the youth would be returned to detention.

TABLE 23

$\begin{aligned} & \text { OUTCOME OF YOUTH WHO DO NOT WANT TO PARTICIPATE } \\ & \text { Close Supervision Staff }\end{aligned}$
$\begin{aligned} & \text { Response } \\ & \text { Return to detention }\end{aligned}$
$\begin{aligned} & \text { N }=4 \\ & \text { n }\end{aligned}$

The respondents again affirm that there are only two choices avallable - detention or the Close Supervision Program. The responses further suggest to the authors the need for alternative programs.

As indicated in the table below, 24 of the responding counselors (50 percent) expected the Close Supervision staff to monitor the youth's behavior. Another 15 ( 31 percent) expected the staff to commicate with them about the youth's behavior as compared with 5 (10 percent) who expected the staff to provide support and superviston.

TABLE 24

EXPECTATIONS OF THE CLOSE SUPERVISION STAFF Juvenile Court Counselors

\section{Response}

To monitor youth's behavior

To communteate with counselor on youth's $3 . ., \ldots$ behavior

To provide support and supervision

No answer

Other

$N=48$
Prequency Percent 24 
The counselors were also asked about their expectations of the youth placed on the program. Out of the total of 33,27 of them (79 percent) indicated that they expected the youth to follow and obey the contract. Responses from 4 (10 percent). showed that they expected the youth to act more responsibiy.

TABLE 25

EXPECTATIONS OF YOUTH PLACED ON THE PROGRAM Juvenile Court Counselors

Response

Follow and obey contract Act more responsibly

Other

No answer

$N=33$
Frequency Percent

\section{6}

4

2

1
79

10

4

Since the majority of the coungelors expected the youth who were placed on the program to follow and obey the contract (to succeed) the authors were led to ask: 1) Does the counselors' high expectations of success in any way jeopardize those youth who fail? 2) Does such a high expectation of success obscure the counselors' view of the extensive use of house custody (one of the specially tailored rules) by the Close Superviston staff?

The respondents were also asked about the rules and restrictions of the Close Supervision Program. As indicated in Table 26, 18 (66 percent) counselors responded positively, 8 (30 percent) responded negatively and 1 ( 4 percent) made no response. 
TABLE 26

\section{COMMENTS REGARDING RULES AND RESTRICTIONS}

Juvenile Court Counselors

Response

Positive comments

Negative comments

No response

$N=27$
Erequency Percent

18

$8 \quad 30$

Those 18 respondents who made positive comments 1isted: good seems to set effective, realistic limits; okay; acceptable; seems fair and necessary to justify release back to the community. The 8 counselors who made negative comments mentioned: not flextble enough; some children cannot handle strict rules; kids do not keep and obey them; and there is infrequent follow through with appropriate consequences.

The Effects of The Program

As indicated in the Tables, 16 coumselors ( 52 percent) and 2 menbers of the Close Supervision Staff (29 percent) expressed that daily contacts helped the youth to avoid further law violations. However, 3 staff members ( 43 percent) did mention that, in their opinton, setting rules was primarily helpful to the youth. Another 7 counselors (23 percent) noted the staff's efforts to find positive activities as being helpful to the youth. 
TABLE 27

AVOIDANCE OF FURTHER LAW VIOLATIONS WHILE ON CLOSE SUPERVISION PROGRAM Juvenile Court Counselors

Response

Dally contacts

Helps youth to find positive activities

Do not know

Other

$N=31$
Frequency Percent

16

52

23

16

10

\section{TABLE 28}

AVOIDANCE OF FURTHER LAW VIOLATIONS WHILE ON CLOSE SUPERVISION PROGRAM Close Supervision Staff

Response

Setting up rules for youth

Dally contacts

Provide a model

Cannot prevent new crimes
Frequency Percent

$3 \quad 43$

$2 \quad 29$

114

14

\section{$N=7$}

A review of the youth who have completed the program successfully tends to support the view that dally contacts were helpful. However, the authors question whether there is a parallel between daily contacts and Schwitzgebel's theory, as presented by Schur (1973), on the use of various electronic devices for the continual monitoring of the geographic location of parolees.

According to 12 counselors ( 32 percent), the youth's impulsive behavior was primarily responsible for the outcome of placement on the program. Another 9 counselors ( 24 percent) noted that the motivation of the youth was also responsible for the outcome on the program. 
WHY SOME YOUTH SUCCEEDED AND OTHERS FAILED Juvenile Court Counselors

$\begin{array}{lcc}\text { Response } & \text { Frequency } & \text { Percent } \\ \text { Some cannot control impulsive behavior } & 12 & 32 \\ \text { Motivation of youth } & 9 & 24 \\ \text { Family situation } & 4 & 11 \\ \text { Inappropriate placement } & 6 & 16 \\ \text { No relationship to the program } & 3 & 8 \\ \text { Other } & 2 & 5 \\ \text { No answer } & 1 & 3 \\ \text { N- } 37 & & \end{array}$

The responses to this question tend to suggest that the Individual was primarily responsible for his own behavior, which could result in success or failure on the program.

As Table 30 and 31 indicate; the majority of the respondents, 25 counselors ( 69 percent) and 4 staff members (100 percent) made positive comments about the changes in the dellvery of services occurring at the Donald E. Long Home. Such comments Included: fewer children being held in detention, provides for additional counseling services, and provides a more Individual program for each youth. The 11 counselors (31 percent) who spoke negatively of the changes stated that the use of the program has made the delivery of services more difficult and slower; has contributed to the weakening of a system; and has not helped the delivery of the services. 
TABLE 30

CHANGES IN SERVICES AT THE DONALD E. LONG HOME Juvenile Court Counselors

Response

Positive comments

Negative comments

$N=36$
Prequency . Percent

$25 \quad 69$

$11 \quad 31$

TABLE 31

CHANGES IN SERVICES AT THE DONALD E. LONG HOME Close Supervision Staff

Response

Positive comments

$N=4$
Frequency

4

100 


\section{CHAPTER VII}

\section{CONCLUSIONS/RECOMEENDATIONS}

With the continued increase of delinquent behavior on both the national and local level it is evident that alternative programs are needed to supplement or replace some of those currently in operation by the Court. It is also very apparent that many of the current programs exacerbate the problem of delinquency and at times create additional problems for the youth.

That alternative programs in lieu of institutionalization can operate successfully is evident by the study just completed. What the study also reveals is that

1) There are limited alternatives for youth who do not require institutionalization.

2) Alternative programs can operate at cost less than that for instltutional care, and still be successful.

3) Such programs can contribute to labeling and stigma as long as they are dependent upon the court for referrals.

\section{LIMITATION OF THE STUDY}

To make a more accurate evaluation of the Program, the authors would have needed to interview the youths who were placed on the Program. For this reason, the study was limited because of a lack of views from the youth. 
The evaluation may also have been limited because many of the juvenile court files were not completed. As a result, pertinent information regarding the youth's family could not be secured. In the authors' opinion, information on the youth's home was needed, since the criteria for placement on the Close Supervision Program stipulated that the youth have a home or surrogate home available.

Other 1imitations, which may have affected the findings of the study included:

1) The evaluation was made on the Program's first five months of operation.

2) There was no control group for a comparative study. RECOMMENDATIONS

Although the Close Supervision Program operated with a great deal of success during the first five months of operation, the authors make the following recommendations to further enhance the program's operations. 1. That the program be continued as an alternative to institutional care. 2. That the program coordinator seek to enlarge the program for the purpose of serving more youths.

3. That the objectives of the program be set forth in quantifiable and measureable terms. 


\section{BIBLIOGRAPHY}

Ahrenfeldt, R. H. and Gibbens, T. C. N. (ed.)

1966 Cultural Factors in Delinquency

London: J. B. Lippincott Company.

Almquist, Terrance A. and Blodick, Gaty R. (ed.)

1968 Readings in Contemporary American Society.

Englewood Cliffs, N.J.: Prentice-Hall, Inc.

Anonymous

1953

Your Juvenile Court,

Portland, Oregon: Multnomah County; Oregon

Anonymous

1958

Multnomah County Juvenile Court and Home

Portland, Oregon: Multnomah County, Oregon.

Anonymous

1965 Multnomah County Juvenile Court and The Donald E. Long Home

Portland, Oregon: Multnomah County, Oregon.

Anonymous

1967 Multnomah County Juvenile Court and

The Donald E. Long Home

Portland, Oregon: Multnomah County, Oregon.

Anonymous

1972 Multnomah County Juvenile Court and The Donald E. Long Home

Portland, Oregon: Multnomah County, Oregon.

Bauman, Christine, Tinda11, Terrence, and Cogan, Mark.

1974 Youth Faces the Law, Metropolitan Youth Commission of Portland and Multnomah County:

Multnomah County and Portland, Oregon.

Bell, Marjorie

1930 The Juvenile Court of Multnomah County Oregon, Report of a Survey

New York City: National Probation Association.

Cavan, Ruth Shonle

1962 Juvenile Delinquency, Development, Treatment, Control, New York: J. B. Lippincott Company.

Cavan, Ruth Shonle.

1962 Criminology New York: Thomas Y. Crowe11 Company. 
Clark, Donald E. Commisstoner

1974 Care of Juveniles in Multnomah County Multnomah, County, Oregon: Multnomah County, Oregon.

Cloward, Richard A., and Ohlin, Lloyd E.

1960 Delinquency and Opportunity, a Theory of Delinquent Gangs. Glencoe, Illinols The Free Press, A Corporation.

Conger, John Janeway and Miller, Wilbur C.

1966 Personality, Soclal Class, and Delinquency New York: John Wiley and Sons, Inc.

Cortés, Juan B. with Gatti, Florence M.

1972 Delinquency and Crime A Biopsychosocial Approach New York: Seminar Press, Inc.

Dahl, Robert (ed.)

1973 Multnomah County Juvenile Court and Donald E. Long Home Report for 1973 Multnomah County, Oregon: Multnomah County, Oregon.

Dahl, Robert (ed.)

1974 Multnomah County Juvenile Court and Donald E. Long Home Report for 1974 Multnomah County, Oregon: Multnomah County, Oregon.

East, Allan

1939 The Genesis and Early Development of a Juvenile Court, a study of Community Responsibility in Multnomah County, Oregon for the period 1841-1920 Department of Sociology Unfversity of Oregon.

East, Allan

1943 A History of Community Interest in a Juvenfle Court, Portland, Oregon Shadows Press.

Giallombardo, Rose, (ed.)

1966 Juvenile Delinquency, A Book of Readings. New York: John Wiley and Sons, Inc. 
Gibbons, Don C.

1965 Changing the Lawbreaker the Treatment of Delinquents and Criminals. Englewood Cliffs, New Jersey: Prentice-Hall, Inc.

Glen, Jeffrey E. and Weber, J. Robert.

1971 The Juvenile Court: A Status Report. Washington D.C. National Institute of Mental Health Center for Studies of Crime and Delinquency.

Goddard, Jewe11

1974 Director, Department of Human Services Multnomah County, Oregon: Interview

Goffman, Erving

1963 Stigma Notes on the Management of Spoiled Identity. Englewood Cliffs, New Jersey: Prentice-Ha1l, Inc.

Griffin, Paul (ed.)

1974 Program Objective Productivity System Multnomah County, Oregon, Office of Planning, Evaluation and Program Development: Multnomah County, Oregon.

Harlow, Eleanor, Weber J. Robert, and Cohen, Fred 1971a Diversion from the Criminal Justice System. Washington D.C.: National Institute of Mental Health Center for Studies of Crime and Delinquency.

Harlow, Eleanor, Weber, J. Robert, and Wilkins, Leslie T.

$1971 b$ Conmunity Based Correctional Programs

Models and Practices. Washington D.C.

National Institute of Mental Health Center

for Studies of Crime and Delinquency

Insley, Jackie

1974 Portland Police, Portland, Oregon: Interview.

Jackson, Louise, T.

1975 Juvenile Court Statistics 1973.

Department of Health, Education, and

Welfare. Washington D.C.: U.S.

Government Printing office. 
Kassebaum, Gene

1974 Delinquency and Social Policy

Englewood Cliffs, New Jersey: Prentice-Ha11, Inc.

Leglslative Interim Juvenile Code Committee

1972 Laws Relating to Children

Salem, Oregon: State of Oregon.

Lemert, Edwin M.

1971 Instead of Court, Diversion in Juvenile

Justice Washington D.C. National Institute

of Mental Health Center for Studies of

Crime and Delinquency.

Office of County Management

1974 Annual Budget Report

Multnomah County, Oregon: Multnomah

County, Oregon.

Perlman, Richard

1968 Delinquency Prevention: The Size of the

Problem: 223-224

Boston: Ginn and Company

(Reprinted in Hirschi, Travis, and Selvin, Hanan C., Delinquency Research, An Appraisal

of Analytic Methods, The Free Press, New York).

Planning, Analysis and Research and Design,

1973 Nultnomah County, Oregon

A Study of Juvenile Detention in Multnomah

County, Oregon, Preliminary Report

Multnomah County, Oregon: Multnomah County, Oregon.

Public Law 93-415, 93rd Congress, J. 821

1974 Juvenile Justice and Delinquency Act of 1974.

Washington: U.S. Government Printing office.

Richette, Lisa Aversa

1969 The Throwaway Chidren. New York:

Dell Publishing Co.

Schur, Edwin M.

1971 Labeling Deviant Behavior: Its Sociological

Implications New York: Harper and Row.

Schur, Edwin M.

1973 Radical Non-Intervention Rethinking

The Delinquency Problem. Englewood Cliffs,

New Jersey: Prentice-Hall, Inc. 
Sweeney, Pat

1974 Coordinator, Close Supervision Program Portland Metropolitan Steering Committee Portland, Oregon: Interview.

Tannenbaum, Frank

1938 "Point of View," Crime and the Community. Boston Ginn and Company: u-22.

(Reprinted in Rose Giallombardo, Juvenile Delinquency, a book of readings, John Wiley and Sons, Inc. New York).

Task Force Report

1967 Juvenile Delinquency and Youth Crime Report on Juvenile Justice and Consultants' Papers Washington: U.S. Government Printing office.

West, D.J. in Collaboration with Farrington, D.P. 1973 Who Becomes Delinquent? London: Heinmann Educational Books Ltd.

Youth Research Group Report No. 1

1975 Issues Relating to Youth Services Bureau Organization, Operation, and Evaluation, Boston, Massachusetts, unpublished. 
APPENDIX A

DEMOGRAPHIC DATA ON COURT COUNSELORS AND CLOSE SUPERVISION STAFF COURT COUNSELORS CLOSE SUPERVISION STAFF

\begin{tabular}{|c|c|c|c|c|}
\hline CATEGORY & NUMBER & PERCENT & NUMBER & PERCENT \\
\hline $\begin{array}{l}21 \text { Age } \\
21-25 \\
26-30 \\
31-35 \\
36-40 \\
41-45 \\
46-50 \\
51-55\end{array}$ & $\begin{array}{l}0 \\
5 \\
7 \\
3 \\
6 \\
2 \\
1\end{array}$ & $\begin{array}{r}0 \\
20 \\
30 \\
13 \\
25 \\
8 \\
4\end{array}$ & $\begin{array}{l}1 \\
2 \\
1 \\
0 \\
0 \\
0 \\
0\end{array}$ & $\begin{array}{l}25 \\
50 \\
25\end{array}$ \\
\hline $\begin{array}{l}\text { Race } \\
\text { Black } \\
\text { White } \\
\text { Other }\end{array}$ & $\begin{array}{r}2 \\
22 \\
0\end{array}$ & $\begin{array}{r}8 \\
92 \\
0\end{array}$ & $\begin{array}{l}1 \\
3 \\
0\end{array}$ & $\begin{array}{r}25 \\
75 \\
\end{array}$ \\
\hline $\begin{array}{l}\text { Mex } \\
\text { Female }\end{array}$ & $\begin{array}{r}18 \\
6\end{array}$ & $\begin{array}{l}75 \\
25\end{array}$ & $\begin{array}{l}3 \\
1\end{array}$ & $\begin{array}{l}75 \\
25\end{array}$ \\
\hline$\frac{\text { Total Year }}{\text { Working }}$ & & & & \\
\hline $\begin{array}{r}1-5 \\
6-10 \\
11-15 \\
16-21\end{array}$ & $\begin{array}{r}3 \\
10 \\
6 \\
5\end{array}$ & $\begin{array}{l}13 \\
42 \\
25 \\
20\end{array}$ & $\begin{array}{l}3 \\
1 \\
0 \\
0\end{array}$ & $\begin{array}{l}75 \\
25 \\
0 \\
0\end{array}$ \\
\hline$\frac{\text { Level of }}{\text { Education }}$ & & & & \\
\hline $\begin{array}{l}\text { Some college } \\
\text { Bachelor } \\
\text { Master } \\
\text { Majors } \\
\text { Sociology } \\
\text { Social Work } \\
\text { Counseling } \\
\text { Psychology } \\
\text { Law Enforcement } \\
\text { Liberal Arts }\end{array}$ & $\begin{array}{r}0 \\
14 \\
10 \\
10 \\
2 \\
2 \\
6 \\
1 \\
3\end{array}$ & $\begin{array}{r}0 \\
58 \\
42 \\
42 \\
8 \\
8 \\
25 \\
4 \\
13\end{array}$ & $\begin{array}{l}1 \\
1 \\
2 \\
1 \\
0 \\
0 \\
2 \\
0 \\
1\end{array}$ & $\begin{array}{r}25 \\
25 \\
50 \\
\\
25 \\
0 \\
0 \\
50 \\
0 \\
25\end{array}$ \\
\hline
\end{tabular}


APPENDIX'B

NUMBER OF YOUTH ASSIGNED TO CLOSE SUPERVISION PROGRAM BY ADMITTING OFFENSE

\begin{tabular}{|c|c|c|}
\hline OFFENSE & NUMBER & PERCENT \\
\hline Unauthorized use of vehicle & 11 & 8 \\
\hline Burglary lst degree & 23. & 17 \\
\hline Criminal trespassing - dwelling & 1 & 1 \\
\hline Loitering - schooi & 1 & 1 \\
\hline Robbery 2nd-3rd degree & 1 & 1 \\
\hline Robbery lst degree & 4 & 3 \\
\hline Theft 2nd degree, shoplift only & 5 & 4. \\
\hline Theft 1st and 2nd degree & 8 & 6 \\
\hline Theft by receiving and concealment & 2 & 1 \\
\hline Forgery & 2 & 1 \\
\hline Rape, forctble & 1 & 1 \\
\hline Prostitution & 1 & 1 \\
\hline Assault 2nd degree & 3 & 2 \\
\hline Homicte & 1 & 1 \\
\hline Arson & 1 & 1 \\
\hline Criminal activity/use of drugs - marijuana & 1 & 1 \\
\hline Criminal activity/use of drugs - other & 4 & 3 \\
\hline Runaway & 23 & 17 \\
\hline Beyond parental control & 36 & 27 \\
\hline Curfew & 1 & 1 \\
\hline Court Order & 3 & 2 \\
\hline TOTAL & 133 & 100 \\
\hline
\end{tabular}


APPENDIX C

DROPPED CASES ON CLOSE SUPERVISION PROGRAM BY AGE, ADMITTING OFFENSE AND NEW OFEENSE

\begin{tabular}{|c|c|c|}
\hline$\underline{A G E}$ & ADMITTING OFFENSE & NEW OFFENSE \\
\hline $\begin{array}{l}16 \\
17\end{array}$ & $\begin{array}{l}\text { Unauthorized use of vehicle } \\
\text { Burglary 1st degree }\end{array}$ & $\begin{array}{l}\text { Passinger in stolen car, curfew } \\
\text { Violated Close Supervision Rules }\end{array}$ \\
\hline 17 & Burlary lst degree & Runaway \\
\hline 15 & Burglary lst degree & Runaway. \\
\hline 14 & Beyond parental control & Violated Close Supervision Rules \\
\hline 13 & Theft 2nd degree, shoplift only & Violated Close Supervision Rules \\
\hline 16 & Runaway & Violated Close Supervision Rules \\
\hline 13 & Beyond parental control & Fight with guardian \\
\hline 16 & Runaway & Runaway \\
\hline 14 & Runaway & Runaway \\
\hline 15 & Burglary Ist degree & Violated house custody, curfew \\
\hline 12 & Theft 1st and 2nd degree & Curfew \\
\hline 14 & Burglary lst degree & Auto theft \\
\hline 16 & Theft 2nd degree, shoplift only & Curfew \\
\hline 14 & Runaway & Pool hall, custody \\
\hline 13 & Runaway & Runaway \\
\hline 14 & Beyond parental control & Runaway \\
\hline 15 & Unauthorfied use of vehicle & Runaway \\
\hline 12 & Beyond parental control & Runaway \\
\hline 15 & Burglary 1st degree & Violated Close Supervision Rules \\
\hline 16 & Beyond parental control & Runaway \\
\hline
\end{tabular}




\begin{tabular}{l|l|l}
\hline AGE & \multicolumn{1}{|c}{ ADMITTING OFFENSE } \\
15 & Beyond parental control & NEW OFFENSE \\
16 & Beyond parental control & Minor in possession of alcohol \\
14 & Beyond parental control & Runaway \\
16 & Runaway & Runaway \\
15 & Unauthorized use of vehicle & Runaway \\
16 & Unauthorized use of motor vehicle & Violated Close Supervision Rules \\
16 & Court ordered & Burglary 2nd degree \\
15 & Beyond parental control & Theft II \\
15 & Beyond parental control & Runaway \\
12 & Beyond parental control & Runaway \\
13 & Beyond parental control & Didn't attend school \\
15 & Criminal activity/use drugs-other & Criminal activity in drugs \\
15 & Burglary 1st degree & Violated Close Supervision Rules \\
15 & Unauthorized use of vehicle & Curfew
\end{tabular}


APPENDIX D

MULTNOMAH COUNTY, OREGON, JUVENILE JUSTICE SYSTEM

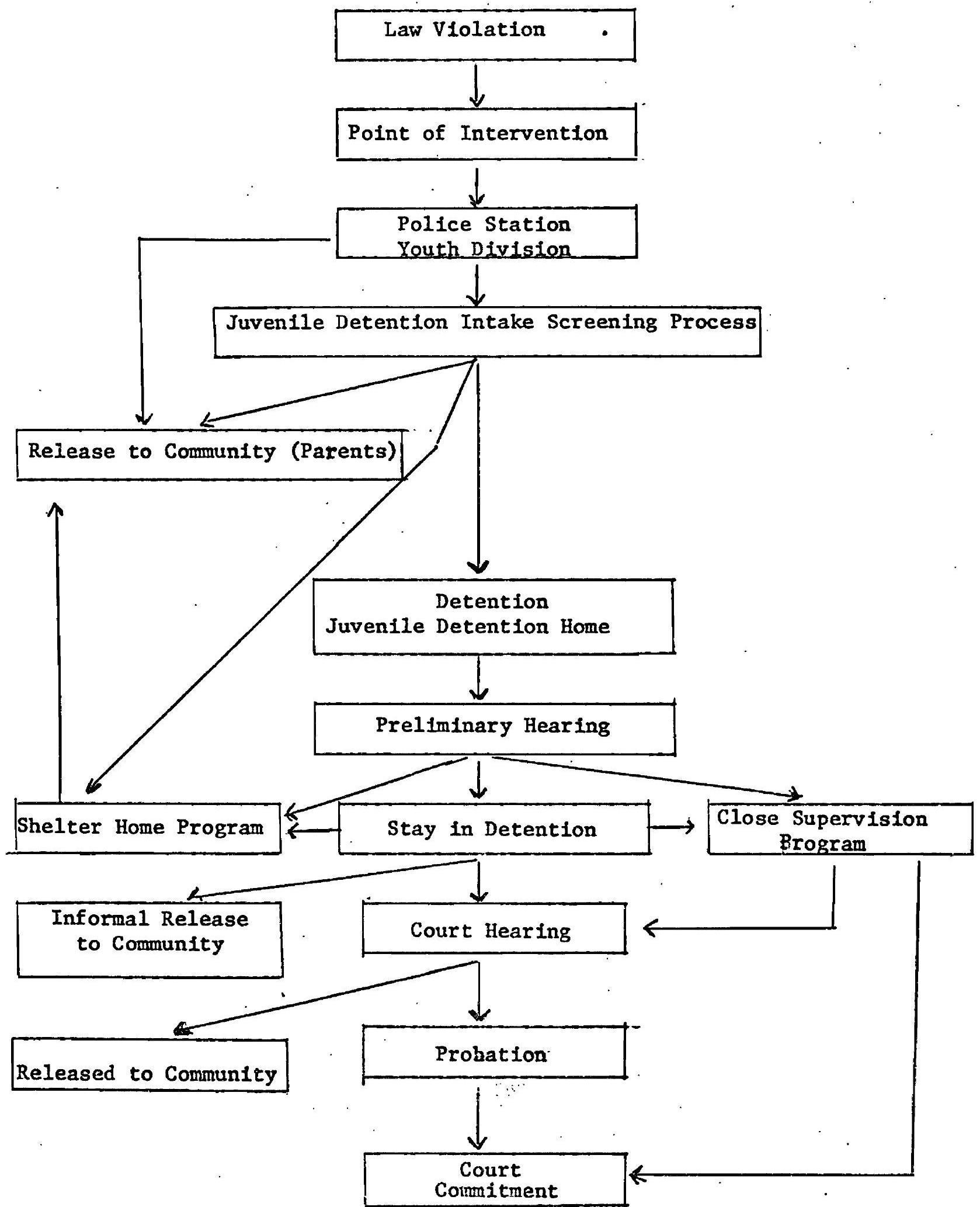


APPENDIX E

MULTNOMAH COUNTY, OREGON, JUVENILE JUSTICE SYSTEM

DETAILS OF THE CLOSE SUPERVISION PROGRAM COMPONENT

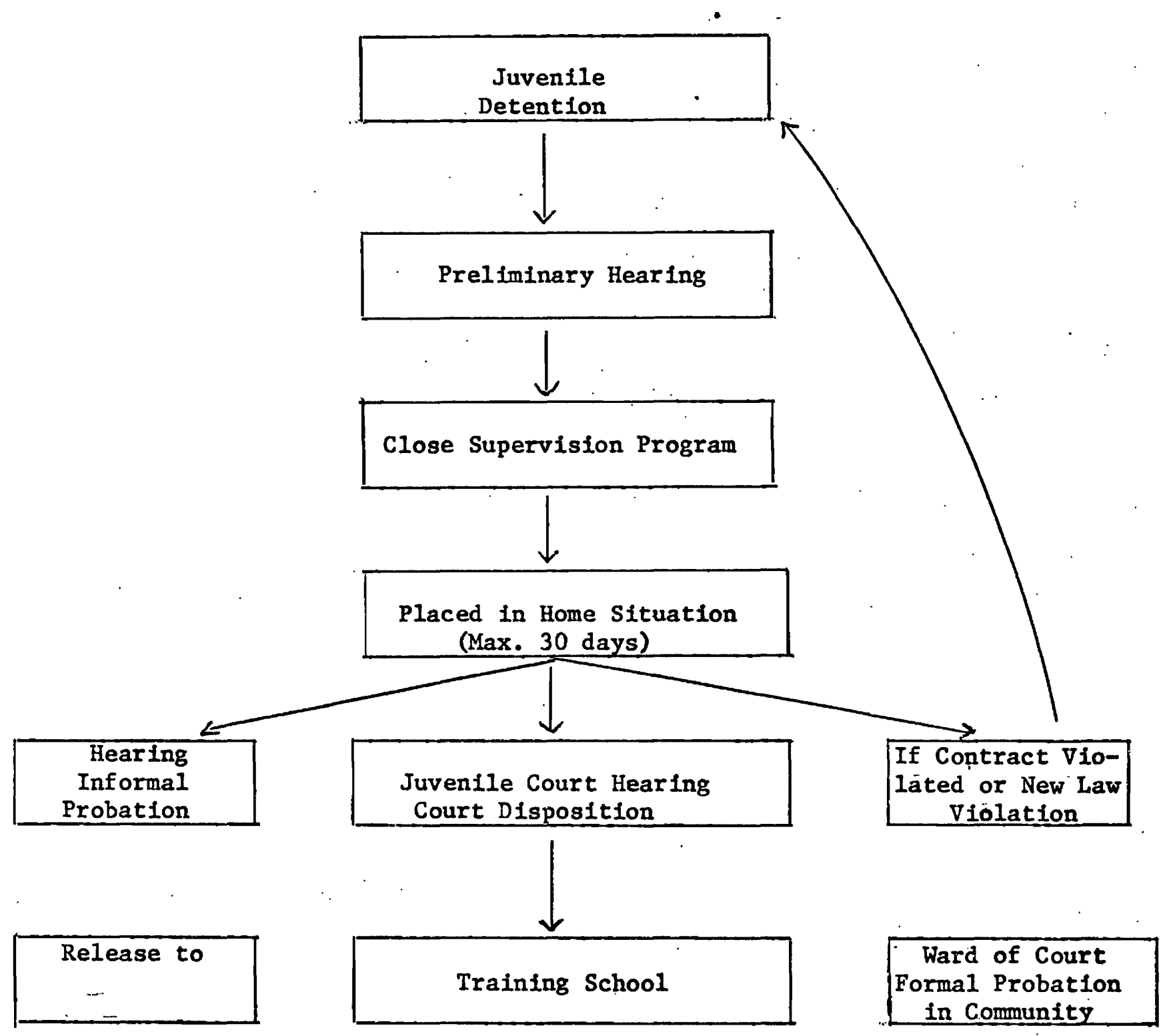


APPENDIX $\mathrm{F}$

\begin{tabular}{|c|c|c|c|}
\hline DEMOGRAPHIC DATA & CATEGORY & NUMBER & PERCENT \\
\hline $\begin{array}{l}\text { Days in detention } \\
\text { before Close Super- } \\
\text { viston }\end{array}$ & $\begin{array}{l}0 \\
1-5 \\
6 \text { or more }\end{array}$ & $\begin{array}{l}42 \\
70 \\
21\end{array}$ & $\begin{array}{l}32 \\
52 \\
16\end{array}$ \\
\hline $\begin{array}{l}\text { Days on Close } \\
\text { Supervision }\end{array}$ & $\begin{array}{r}1-5 \\
6-10 \\
11-41 \\
42 \& \text { over } \\
\end{array}$ & $\begin{array}{r}8 \\
15 \\
96 \\
14 \\
\end{array}$ & $\begin{array}{r}6 \\
11 \\
72 \\
11 \\
\end{array}$ \\
\hline Referral offense & $\begin{array}{l}\text { Status } \\
\text { Sertous } \\
\text { Court Ordered } \\
\end{array}$ & $\begin{array}{r}60 \\
71 \\
2 \\
\end{array}$ & $\begin{array}{r}45 \\
53 \\
2 \\
\end{array}$ \\
\hline Previous offense & $\begin{array}{l}\text { Yes } \\
\text { No } \\
\end{array}$ & $\begin{array}{r}101 \\
32 \\
\end{array}$ & $\begin{array}{l}76 \\
24 \\
\end{array}$ \\
\hline $\begin{array}{l}\text { Type of Previous } \\
\text { offense } \\
\text {. }\end{array}$ & $\begin{array}{l}\text { Status } \\
\text { Serfous } \\
\text { Both } \\
\text { None } \\
\end{array}$ & $\begin{array}{l}23 \\
35 \\
42 \\
33 \\
\end{array}$ & $\begin{array}{l}17 \\
27 \\
31 \\
25\end{array}$ \\
\hline Service Completed & $\begin{array}{l}\text { Yes } \\
\text { No } \\
\end{array}$ & $\begin{array}{l}98 \\
35 \\
\end{array}$ & $\begin{array}{l}74 \\
26 \\
\end{array}$ \\
\hline Reason Dropped & $\begin{array}{l}\text { New Crime } \\
\text { Close Supervision } \\
\text { Violation } \\
\text { New Crime/Close Super- } \\
\text { vision Violation } \\
\end{array}$ & $\begin{array}{c}26 \\
8 \\
1 \\
\end{array}$ & $\begin{array}{r}74 \\
23 \\
3 \\
\end{array}$ \\
\hline Court Attendance & $\begin{array}{l}\text { Yes } \\
\text { No } \\
\end{array}$ & $\begin{array}{l}69 \\
64 \\
\end{array}$ & $\begin{array}{l}52 \\
48 \\
\end{array}$ \\
\hline
\end{tabular}

Demographic data on youths assigned to the Close Supervision Program. 


\section{Milutinomaln Coumty Oresom. INTER-OFFICE MEMORANDUM}

TO: Co-Workers and Friends C. D. Crawford, Director FROM: Residential Services
SUBJECT: New Program: Close Supervision

DATE: $\quad 4 / 19 / 74$

Close Supervision is a new program in the Department of Residential Services. Six staff members have been appointed to initiate a program of supervision in the home and community of children who would otherwise be in custody at the Donald E. Long Home. This is a new alternative to secure custody for children who need more supervision than the family is able to provide while awaiting a Court disposition on delinquency charges.

The six Community Youth Workers will be assigned up to five young people from the Detention Home. These children will be released to their home with the understanding that they will not become involved in further delinquency while awalting Court action and will be available for Court appearance if required. This usually will be a period of less than three weeks. Supervision will involve at least two face-to-face contacts each day with the child and contacts with the school, employers, ministers, and other people significant to the child. This program has been patterned after a similar successful program of Home Detention in St. Louis, Missouri.

Attached to this memorandum is an outline of the program and a description of the job expectations for Community Youth Workers. Also included is a copy of the Child-Parent Agreement. Gary Long has been chosen to coordinate this new program and can be reached to discuss it or answer questions at $248-3481$ or $248-3489$.

$\mathrm{CDC}: \mathbf{k k}$ 


\author{
ATTACHMENT B \\ MULTNOMAH COUNTY \\ CLOSE SUPERVISION PROGRAM \\ DEPARTMENT OF RESIDENTIAI SERVICES \\ JOB EXPECTATIONS • \\ COMMUNTY YOUTH WORKER
}

GENERAL

The Community Youth Worker is under direct superviston of the Close Supervision Coordinator of the Department of Residential Services.

The primary purpose, the Community Youth Worker is to provide supervision for children released from the Juvenile Detention Home to their own homes or surrogate homes, who otherwise would need secure custody.

The CYW must be able to develop a close relationship with children and provide consistent supervision for the delinquent child. The duties are varied and demanding, Involving close attention to all aspects of "child care" and protection.

The CYW must be able to disconcern himself with the child's offense in the care of the child, although he may be aware of the offense. He is not a Juvenile Court Counselor or Case-aide.

DUTIES (Genera1)

Administratively, Community Youth Workers will work in teams of two each. This would enable workers to assume responsibility when one is unavailable or absent for reasons of 11 lness, etc. Community Youth Workers will not be 1 imited to areas of specific geographical boundaries for reasons of program flexibility..

The Community Youth Worker will be required to keep in close daily touch with the child and his parent, school and any others who are significant in the child's life. The Youth Worker would encourage any of these to call him freely and quickly in case of any problems that may be prevented from escalating. He shall visit the home and school on a nearly daily basis and keep the Juvenile Court Counselor informed about the child's progress.

In addition to contacts related to emergency matters, the Community Youth Worker will arrange activities of various kinds, $1 . e$. , attending community programs of various $\mathrm{kinds}$, bowling, movies, better recreational activities no matter how unconventional as long as it seems useful in stabilizing the child.

DUTIES (Specific)

Responsibility to maintainstandards and function within the guidelines of the Close Supervision Program. 
Responsibility to maintain dally alert supervision of the child's activities at home, in school, in the neighborhood and at work.

Responsibility to be aware of all matters pertaining to safety and behavioral adjustments of the child and to communicate with the child's counselor and the Program Coordinator through appropriate written and oral reports.

Responsibility to supervise and direct child activities relative to participant involvements, and at times initiate constructive activities.

Responsibility to assist and cooperate with all authorized agents having legitimate business with the child, including police, volunteers, parents, educators, clergy, and other such persons.

Responsibility to abide by and accept any and all such directives relative to job functions as the Close Supervision Coordinator may from time to time direct.

Responsibility to attend a weekly staff meeting. 
ATTACHMENT C

CLOSE SUPERVISION PROGRAM

I. Program Objectives

A. To provide a program for supervision and control of youth in Multnomah County who would otherwise be placed in The Donald E. Long Home.

B. By implementation of this program, to reduce the number of youths held in secure detention pending disposition and implementation of Court plan.

II. Program Goals

A. Personnel Structure

1. Program Coordinator

2. Community Youth Workers

B. Referral Procedure

1. Screening Criteria:

a. The youth must have a home ava1lable, natural or substitute;

b. The case is not so notorious to render the youth unacceptable to the community;

c. A Community Youth Worker is available who can assune supervision.

2. Screening Procedure

The coordinator shall:

a. Interview youths who have been in The Donald E. Long Home for three (3) days, to determine suitability for the program;

b. Contact the Juvenile Court Counselor and discuss suitability for placement; 
c. Contact the parents to discuss the program and their cooperation;

d. Assign a Community Youth Worker;

e. Make arrangements for child to be released, at which time the assigned Youth Worker and Counselor will explain the program In detall to the parents.

f. Juvenile Court Counselors may also refer youths to the coordinator for consideration.

c. The role of the Community Youth Worker

1. Carry a maximum caseload of five (5) ?

2. When possible, use team work approach;

3. Make at least two face-to-face contacts daily with each youth;

4. Maintain contact with parents, schools and community resources;

5. Work with the Juvenile Court Counselor;

6. Involve and supervise youths in constructive activities;

7. Maintain flexible hours and avallability;

8. Submit activity reports as required;

9. Participate in orientation, training and review meetings.

D. Termination Procedure

1. Youths in the program will be terminated upon disposition and Implementation of plan (maximum of 3 weeks) or by request of J.C.C.

2. Youths may be returned to The Donald. E. Long Home for:

a. A new law violation;

b. Lack of cooperation on the part of the youth and/or the parents. 
IV. Program Evaluation

A. Presence of the youth for any scheduled Court hearings.

B. Incidence of delinquency while on the program.

Revised for $4 / 18 / 74$ 
POSITION DESCRIPTION

PORTLAND MITROPOLITAN STERRING COMMITTEE - EOA (InC.)

JOB TITLE: Lead Community Youth Norkex

FUINDAMEITTAL OBJECTIVE :

The Lead Community Youth Worker is responsible for providing supervision for children released from the Juvenile Detention Home while awaiting Juvenile Court. action. In adaition, provides mid-level supervision of the Community Youth Norker Staff.

REPORTS TO: Close Supervision Coordinator

SUPERVISORY

PESPONSIBIIITY: Mid-Level Supervision

Insure Community Youth Workers are meeting required contacts with cases, and maintaining communications with court counselor.

DUTIES \&

RESPONSIBILITIES: To develop a close relationship with children in
assigned caseload and provide consistent supervision for them.

To interpret and explain Close Supervision program "Rules of Supervision" to parent and child.

To maintain standards and function within the guidelines of the program.

To make at least two (2) face-to-face contacts with the child each day and to maintain contact with other persons significant to the childs' well being.

To maintain an awareness of all matters pertaining to the safety and behavioral adjustments of the child.

To communicate with the childs" Juvenile court Counselor and Program Coordinator through appropriate oral and written reports.

To supervise and direct child activities relative to participant involvements, and from time to time initia constructive activities.

To assist and cooperate with ail authorized agents having legitimate business with the child.

To work closely and harmoniously with assigned team members. 


\section{$\underline{2}$.}

To abicie by and accept all directions relative to job function as directed by the close supervision Coordinator.

To be available for emergencies and attend weekly staff meetings.

LI:IIT'S OF

AUTHORITY: TO perform the above duties within the limits of OEO, DOL, HEW, and PISC policies and procedures and within the limits of city, county, state and federal laws. 


\section{PORTLAND METROPOLITAN STEERING COMMITTEE CLOSE SUPERVISION PROGRAM}

The Multnomah County Department of Residential Services has contracted with the Portland Metropolitan Steering Committee to establish and operate a Close Supervision Program as an alternative to secure Detention for juveniles referred to the Multnomah County Juvenile Court.

The PMSC Close Supervision Program, as it is called, maintains a staff of four Community Youth Workers and a Program Coordinator to provide the services contracted for.

The philosophy of the Program is that many of the juveniles referred to the Court do not require the secure custody of the Juvenile Detention Home while

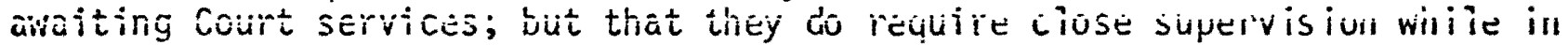
the cominunity.

The criteria for admittance of a juvenile into the Program is that:

(1) he or she have a home available, either the natural one or a surrogate;

(2) the case is not so notorious as to render the juvenile unacceptable to the community;

(3) all parties involved with the case (parents, Juvenile Court Counselor, Community Youth Worker assigned, and the juvenile) agree to maximum participation in the Program.

Once a juvenile is admitted to the Program, he is assigned a Community Youth lorker. It is the responsibility of the Community Youth ilorker to initially orient the juvenile to the Program and to any special rules which have been tailored for the juvenile. While on the Program, the juvenile's behavior will be monitored by the CYW through daily contacts with the juvenile, parents, school officials, employers and other interested parties. Secondary duties are to provide and introduce a variety of healthy activities the child may pursue after he is no longer on the Program.

A juvenile is closed off of the Program when he attends his court Hearing which is approximately 21 days on the Program. He may, also, be terminated from the Program for committing a new law violation or if he fails to follow the rules of the Program. If a juvenile is terminated, he is returned to Detention to await his Court llearing. 
. JRTLAND METROPOL ITAN STEERING COMPITTEE

CLOSE SUPERVISION PROGRAM

Page 2

The Juvenile Court Councelor and the Community Youth Worker maintain an activity line of communication as to the juvenile's behavior and progress while on Close Supervision. When the juvenile attends his Court Hearing, a report is submitted by the Community Youth Worker concerning the juvenile's overall performance while on the Program. The Community Youth Worker may also attend the Court Hearing and provide information which may have a bearing on the Court disposition.

We, at the Portland Metropolitan Steering Committee feel that a program of this nature can be very beneficial to a juvenile who would otherwise be institutionalized, pending his Court Hearing. If you wish further information concerning the. Program, feel free to contact me --

Patrick Sweeney Program Coordinator PMSC Close Supervision Program $1110 \mathrm{~S}$. E. Alder Street Portland, Oregon 97214

Phone: (503) 238-4631

PS: gpw 
IN THE INTEREST
A CHILD UNDER 18
YEARS OF AGE

CLOSE SUPERVISION PROGRAM

DEPARTMENT OF RESIDENTIAL SERVICES

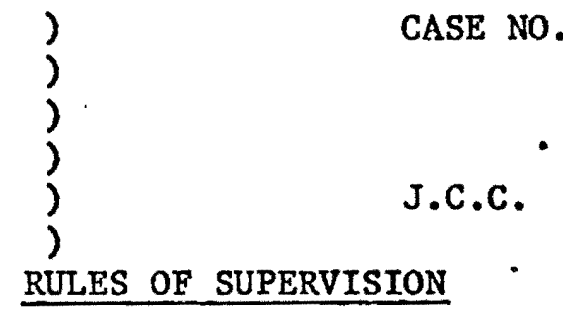

You have been placed by the Department of Residential Services into the Close Supervision Program. This means that we believe you, with the help of your parents and the Community Youth Worker can be a good citizen pending disposition by the Court on your case. As a sign of good falth on your part, the Court requires that you live within the general and spectal rules of supervision which are listed below. If you fail to abide by any of these rules, it may be necessary to return you to the Juvenile Detention Home pending your Court Hearing.

1. Obey the laws of Federal, State and Local Government.

2. Attend school regularly unless excused by proper authority.

3. Make reasonable attempt to keep employed if you are excused from school.

4. Be in your place of residence at the hour designated, and remain therein during the night, as approved by your parents, your Juvenile Court Counselor, or the Community Youth Worker.

5. Obey your parents, the Court, Juvenile Court Counselor, and Community Youth Worker.

6. Avold all companionships and places which may lead you into trouble, or which are not approved by your parents, your Juvenile Court Counselor, or Community Youth Worker.

7. Notify your Juvenile Court Counselor and Community Youth Worker of any change of address.

8. Keep all appointments with your Juvenile Court Counselor unless excused by proper authority.

9. Parents and Legal Custodians: To cooperate in helping and assisting this child to abide by the Rules of Supervision.

SPECIAL RULES

These rules of Supervision have been read and explained to me, and I agree to abide by them.

DATE :

DATE :

SIGNATURE OF CHILD

SIGNATURE OF PARENT

DATE: 
POINLAND MULROPOLIMIAN STEERING COMNITTEE

CLOSE SURERVISIOH PIOGRNII

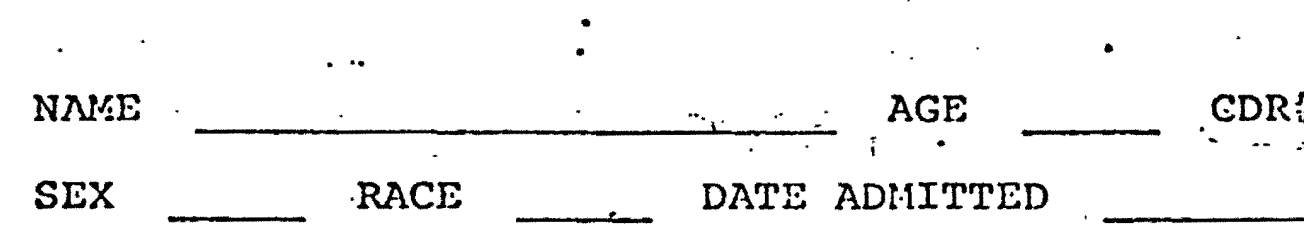

ADDRESS RESIDING $A T$

CT. DATE

$\vdots:$
$\cdot$
$:$
MOTIIER

$\Lambda T$

PIIONE

FATHER

IVORK PIIOINE

TWORK PHONE

SCHOOL ATTENDING

GRADE LEVLL

EMPLOYER

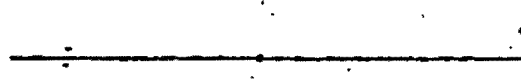

POSITION

ADDRESS

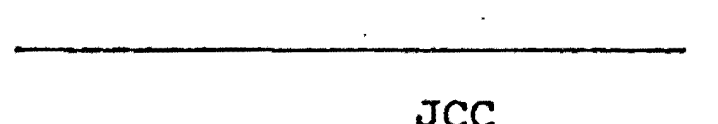

PIHONE

CYIT

JCC

PHONE

CSD CASETORKER

PHONE

גדong:Ty

rYONE

DATE PELEASED

COMMEins 
PMSC CLOSE SUPERVISION PROGRAM

\section{CLIENT EVALUATION}

Number of days on Close Supervision $\cdot$

1. Did you feel the PMSC Close Supervision Program was of any benefit to you. No Benefit Some Benefit Very Beneficial

2. Did you feel your Community Youth Worker was of any help to you. Never Sometimes All The Time

3. Did you feel you could talk freely with your Community Youth Worker. Never Sometimes

Al1 The Time

4. Did you feel that the PMSC Close Supervision Program was too restrictive on you.

Never Sometimes

All The Time

5. Do you feel that the PMSC Close Supervision Program should continue in operation.

$$
\text { Yes__ No. }
$$

Feel free to make any comments you may have concerning the Close Supervision Program. 


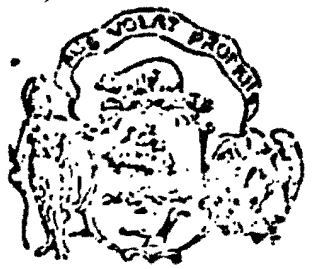

\section{Mr.}

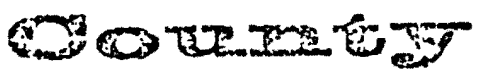

P.jux

BOARD OF COUNTY COAMISSIORIEKS

(503) 2483-3334 * RODM 605, COUNTY SOURT HOUSE - PORTLAND. OREGON - 972O4

July 25, 1974

Portland Metro Steering Comm - EOA-Inc.

$1110 \mathrm{~S}$. E: Alder

Portland, Oregon 97214

Attn: Lorraine Duncan

Mr. Jewel Goddard, Director

Dept. of Human Services

1514 Georgia-Pacific Bldg.

Portland, Oregon

Juvenile Court \& Home

1401 N. E. 68th Ave.

Portland, Oregon

Attn: Mr. Robert Holm

Dear Sirs:

Be it remembered, that at a meeting of the Board of County Commissioners held July 25, 1974, the following action was taken:

In the matter of the execution of an Agreement with the Portland Metropolitan Steering Comittee EOA, (INC), to implement a Close Supervision Program for juventle persons coming within the custodial protection of the Juvenile Court and Donald E Long Home - July 1, 1974 to June 30, 1975

- Mr. John D. Rice, Director Dept. Administrative Services Fiscal Management Division 804 Court House

Attn: Mr. Ralph Hawkfns, Accounting Manager

Mr. Ross M. Hall, Comptroller Budget office

805 Court House

The above-entitled matter having come before the Board and full consideration having been given thereto, upon motion of commissioner clark, duly seconded by Commissioner Gordon, it is hereby unanimously

ORDERED that Multnomah County, Oregon, enter into the aboveentitled Agreement tendered to and before the Board this date, and that the Chairman of the Board be and he is hereby authorized and directed to execute said Agreement for and on behalf of Multnomah County, Oregon.

$$
\text { Yours very truly, }
$$
Encs - AGRMNT in dup to EOA
for exec

Please return one fully executed BOARD OF COUNTY COMMISSIONERS

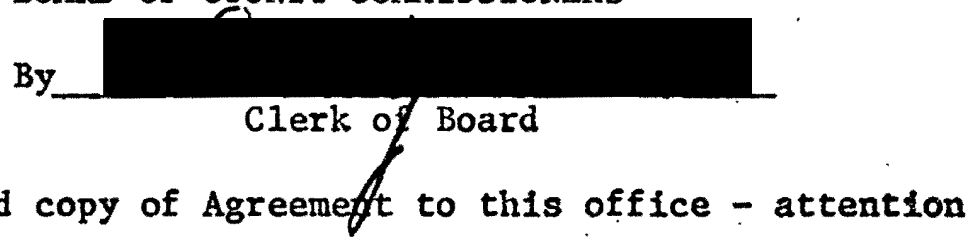


- A G R E I E N T

THISS AGREEILINT by and between MULTNOILAH COUNTY, a political subdivision of the State of Oregon, hereinafter called "County," and PORTIAIN MEIROPOIITAN STEERTING COITITTEE--EOA, (IINC.), hereinafter referred to as "PIiSC,"

WITNES S TH:

WHEREAS, County desires to implement a Close Supervision Program for juvenile persons coming within the custodial protection of the Multnomah County Juvenile Court and the Donald E. Iong Juvenile Home; and

WHEREAS, PMSC is qualified and prepared to furmish to the County a Close Supervision Program that will best suit the needs of certain juvenile persons coming within the custodial protection of the County; now, therefore

IN CONSIDERATION OF THE IUUTAL COVENANIS HEREIN CONTAIHED and for other good and valuable consideration, the parties hereto agree as follows:

1. County will allot funds to PISS in the minimum amount of Fifty-Eight Thousand, Seven Hundred Sixty-Five Dollars $(458,765.00)$ for the period July 1, 1974, through June 30, 1975, upon condition that PISC guarantee to provide its Close Supervision Program service for at least twenty (20) clients per day. 
2. County will allot funds in addition to the sum of $\$ 58,765.00$ in an amount not to exceed the sum of Seventeen Thousand, Eight Hundred Eighty-Five Dollars $(\$ 17,885.00)$ for the period July I, 1974, throuch June 30, 1975, for the care of not wore than ten additional clients. The additional suri will be based on the number of clients times the nuraber of day's care times the sum of $\$ 4.90$ per client per day.

Further, Ccunty will not without contractual modifications, o.greed to by both parties, increase at any period the number of referrals as provided for in the preceding two paracraphs.

3. County will act as the primary referral source for PISC's program in juvenile delinquency cases meeting County's criteria for juveniles eligible for PrisC's Close Supervision Program.

4. County will provide technical assistance to PIMSC as is required to adequately correlate juvenile delinquency policy pertaining to PMSC's Close Supervision Program and to assist PISC to successfully carry out said program.

5. County will provide PIMSC with such information as PIISC requires concerning referred juvenile persons provided that such information is permitted by Juvenile Court through a duly authorized.counselor.

Further, County will initiate the furmishing of information from other programs and administrations as is necessary for PI'SC to continue adequate Close Supervision Program community linkages. 


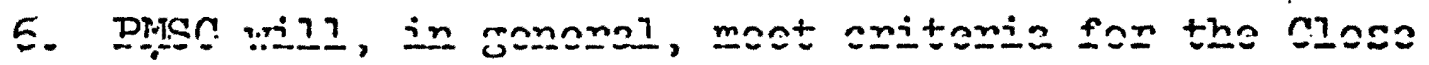
Supervision Program as stipulated in Multnomah County Oregon, Interoffice Memorandum; New Program: Close Supervision; To: Co-Workers and Friends; From: C. D. Crawford, Director, Residential Services; dated 4/19/74; Attachment A.

7. PMSC will continue as a basis for its Close Supervision Program Community Youth Worker job description, duties and responsibilities of said workers as explained in Multnomah County, Close Supervision Program, Department of Residential Services, Job Expectations, Community Youth Worker, dated 4/18/74, with the exception of GEIJRAI, paragraph 1, Attachment. B.

8. PISC vijl continue withir its Close Supervision Program stipulations as appear in Close Supervision Prosram, revised 4/18/74, itens I through IV, Attachment C.

9. PMSC will iliclude within.its Close Supervision Program manning table a Coordinator who will assume direct supervision of program operation and assigned personnel.

10. Payment will be nade to PMSC by County not later than the 15th day following receipt, by County of PrisC's billing for each preceding month.

11. The period of this agreement shall be from July 1 , 1974, to and including June 30, 1975, unless extended by agreement of the parties.

12. This agreement may be terminated at any time prior to the agreed upon period by either party upon thirty (30) dáys' written notice. 
13. PISC is deemed to be an independent contractor. as party to this agreement and agrees to hold the County harmless from all claims arising from the carrying out of its obligations under this agreenent.

14. The narties resenoizing the need fon considerehle flexibility in carrying out the promises, covenants and conditions contained herein, agree that infornal modification of procedure or method may be permitted by agreement of the parties where the substance of the agreement is not affected.

IN WITIESS WHEREOP, the parties hereto have caused this agreement to be execuiced by their duly authorized officens as of the day and year first hereinabove written. initis 25,1974

APPROVED AS TO FORM:

MULTITOMAH COUNTY, OREGON BOARD OT COUITY COIIIISSIONERS

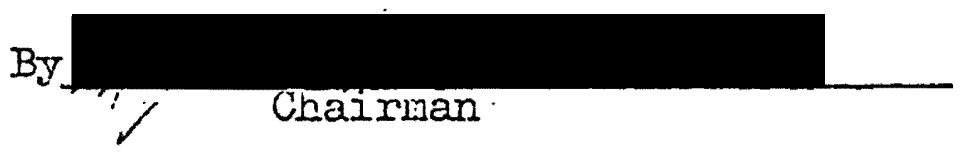

PORTLAIND IEIRROPOIITIII STEERIITG COIIIITTEE EOA, (IITC.)

By

Charles í. Livans

County Counsel for

Irultnomah County, Cregon

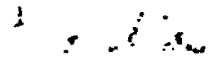

Page 3 - Agreement (Miltnomah County and Portland Istropolitan Steering Committee-20.s, (Inc.) ) 


\section{APPENDIX I}

WORKING AGREEMENT BETWEEN THE PORTLAND METROPOLITAN STEERING COMMITTEE AND MULTNOMAH COUNTY DEPARTMENT OF RESIDENTIAL SERVICES

The Multnomah County Department of Residential Services herein enters into written agreement with the Portland Metropolitan Steering Committee to establish a Close Supervision Program as an alternative to secure detention for juveniles.

This agreement is to set out some specific areas of responsibility for the program of Close Supervision contracted to Portland Metropolitan Steering Conmittee by Multnomah County. In this program, Portland Metropolitan Steering Committee will provide a staff including one Close Supervision Coordinator and a minimum of four Community Youth Workers. Supervision of Community Youth Workers Staff:

The supervision of Community Youth Workers staff will be the responsibility of the Portland Metropolitan Steering Committee and its Close Supervision Coordinator and will follow the guidelines in Contract At tachment C. Item 2, C.

In Subsection (9.) of that Item, the Department of Residential' Services will provide assistance in these activities as needed (orfentation, training and review or staff meetings).

The Portland Metropolitan Steering Committee Close Supervision Coordinator will schedule a weekly staff meeting with the Community Youth Workers staff to discuss policy and case progress and/or problems. A Department of Residential Services staff person will participate in these meetings when appropriate. 
101

$-2-$

\section{Communication:}

It is essential that the Community Youth Workers be available for messages and in communication with the juvenile, his counselor and the Department of Residential Services.

To implement this, the Department of Residential Services will provide a 24 hour message service at the Donald E. Long Home. This will Include a box where written messages may be left and telephone service where messages may be received and relayed.

Portland Metropolitan Steering Comittee will be responsible to have its Community Youth Workers staff telephone twice a day to check for messages (preferably before noon and again before 8:00 p.m. each day) and leave a telephone number where they may be reached if they plan to be away from their home phone for an extended period. If another Community Youth Worker is temporarily supervising a caseload for an assigned CommunIty Youth Worker, that information must be left at the telephone message center also.

\section{Assignments:}

Screening and clearance for release into Close Supervision will be the responsibility of the Department of Residential Services and will follow the Referral and Screening procedures in Contract Attachment C. Item II B, with the understanding that in $\# 2$ of that item, the term "Coordinator" refers to a Department of Residential Services staff person, and in subsection (d.) of that item, the assignment will be done by the Portland Metropolitan Steering Committee Close Supervision Coordinator, assisted by the above sțaff person. 
In Subsection (3.) of the same above item, explanation of the program will be done initially by Juvenile Court or Residential Services staff. Arrangements for actual supervision on a day-to-day basis will be worked out by the Community Youth Worker with the family involved.

Portland Metropolitan Steering Committee Close Supervision Coordinator will have Community Youth Worker staff available for same day release from detention and admission of a child to the Close Supervision Program when notified of the assignment to the program before noon of that day.

\section{Terminations:}

When a child is terminated from the Close Supervision Program, the Department of Residential Services staff will notify the Portland Metropolitan Steering Committee Close Supervision Coordinator. Terminations w111 generally follow Contract attachment C Item II Section D., with the exception that upon occasion a child may be carried on the program longer than the three week perlod specifled.

When it is necessary to terminate a young person for lack of cooperation, his return to detention must first be cleared by the Department of Residential Services. The Community Youth Worker assigned to that case must contact Residential Services and secure a clearance before returning the child to the detention home.

When a court date is set for a child on Close Supervision, it is the responsibility of the Communtty Youth Worker to bring and/or insure that the child is in Court. 


$$
-4-
$$

When a child is terminated from the Close Supervision Program, the Portland Metropolitan Steering Comittee Close Supervision Coordinator will provide the Department of Residential Services with a brief week by week summary of the child's progress and/or problems and behavior while in the program.

Meetings:

A meeting will be held at least once a month for the purpose of reviewing or revising the current policies and practice of the close Supervision Program.

MULTNOMAH COUNTY CORRECTIONS DIVISION RESIDENTIAL SERVICES

$$
\text { By }
$$

Director

PORTLAND METROPOLITAN STEERING COMMITTEEEOA, (INC.)

By

Date: 
JUDGES

MERCEDES F. DEIZ HARLOW F. LENON JEAN L. LEWIS

GEORGE A. VAN HOOMISSEN
MULTNDMAH CDUNTY JUVENILE CDURT AND

DONALD E. LDNG HOME

140IN. E. 68TH AVENUE PORTLAND, OREGON 97213 $240-3460$

December 30, 1974

Thomes Wright, Jr.

3242 \%. E. 58 th

Portland, Oregon 97213

Dear Mr. Wright:

We are pleased to receive your request to research the Close Supervision Program. I understand that this is in connection with your graduate work at the Portland State Oniversity Graduate School of Social Work.

You are authorized to review our case files of the children referred to the Close Supervision Program for information on the questionnaire submitted. I would request that you tabulate your information by the child's case number rather than the child's name or parents name. This will simplify the matter of confidentiality.

\section{Vers truily rours.}

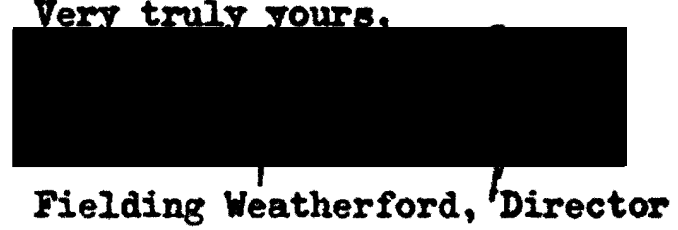

Multnomah County Juvenile Court

IN:vo 
APPENDIX $\mathrm{K}$

PROGRAM EVALUATION

CLOSE SUPERVISION PROGRAM

We, the undersigned graduate students at the School of Soclal Work, Portland State University, request your assistance in the completion of the attached questionnaire on the close Supervision Program.

This research is conducted primarily to fulfil graduation requirements, and will have no adverse effects on your involvement with the Juvenile Court. Your particlpation is voluntary. We also want to. assure you that the information you supply will be held in strictest confidence.

We appreciate your cooperation in helping us to conduct this study which will assist in the dellvery of services to youth involved in the Juvenile Justice System.

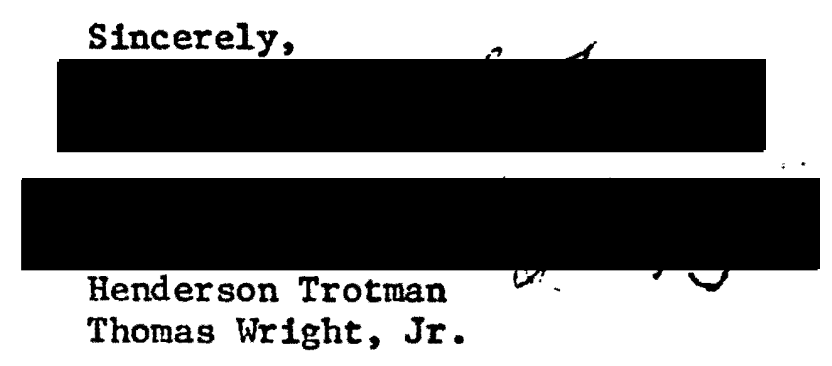


1. Between August. 1 - December 31, 1974, how many juveniles did you place on the Close Supervision Program?

2. What are the objectives of the Close Supervision Program?

3. What are your comments concerning the eligibility requirements for admission to the Close Supervision Program?

4. What kind of Juvenile is the Close Supervision Program designed to serve?

5. Why do you feel there is need for the Close Supervision Program in Multnomah County?

6. How do you determine which juveniles from your caseload will be placed on the Close Supervision Program?

7. What are your expectations of the Close Supervision's staff relative to the juveniles you place on the program?

8. What are your expectations of the juveniles you place on the close Supervision Program?

9. What would happen to a youth who meets the eliglbility requirements but does not want to participate on the Close Supervision Program?

10. What role do you play in relation to the juventles you place on the Close Supervision Program? 
FORM A $-\mathrm{p} .2$

11. What are your comments concerning the rules and restrictions of close Supervision Progran?

12. How does the Close Supervision Program help the fuventles to avold further law violations while they are on the program?

13. Why do you think some juveniles succeeded and others falled on the Close Supervision Program?

14. How has the Close Supervision Program changed the delivery of services to juveniles at the Donald E. Long Home?

COMMENTS : 
FORM B

PROGRAM EVALUATION

QUESTIONNAIRE ON CLOSE SUPERVISION PROGRAM

1. What kind of services and activities did you provide the fuveniles you supervised on the Close Supervision Program?

2. In what ways were you most helpful to the juveniles on the Close Supervision Program?

3. Why do you feel there is a need for the Close Supervision Program In Multnomah County?

4. What are the objectives of the Close Supervision Program?

5. What kind of juvenile is the program designed to serve?

6. How does the Close Supervision Program help juveniles to avoid further law violations while they are on the program?

7. What would happen to a juvenile if the Individual said he did not want to continue on the Close Supervision Program?

8. How has the Close Supervision Program changed the delivery of services to juveniles at the Donald E. Long Home? 
APPENDIX N

FORM C

YOUTH DATA COLLECTION

FILE \#

AREA OF CITY

AGE _ SEX RACE _ _ _

SCHOOL ATTENDING

GRADE LEVEL

EMPLOYMENT

OCCUPATION

JCC

CYW

REFERRAL SOURCE

REFERRAL OFFENSE ( $\mathrm{S}$ )

CRITERIA FOR SELECTION TO CSP

DAYS IN JDH BEFORE CSP DAYS ON CSP

NUMBER OF TIMES ON CSP NUMBER OF PREVIOUS OFFENSES

TYPES OF PREVIOUS OFFENSES

REASON FOR RELEASE FROM CSP

COURT ATTENDANCE YES ( ) No ( )

COURT DISPOSITION

ADDITIONAL SERVICES BY CYW 